\title{
"Fighting Fire with Fire": Rethinking the Role of Disgust in Hate Crimes
}

\author{
Kathryn Abrams $\dagger$
}

How should communities respond to crimes expressing hate, not merely toward an individual victim, but also toward the larger group of which that victim is part? This question is not new: it has been framed, domestically, by the emergence and flourishing of identity politics; it has been underscored, beyond U.S. borders, by efforts to address war crimes and genocide born of group-based antagonisms. But the tragedies of September 11, 2001, have framed this question with distinctive urgency. Fierce hatreds fueled the attacks themselves. These acts then triggered a wave of violence against Arab Americans, Muslims, and others assumed to be of Middle Eastern origin. ${ }^{1}$ Though this wave appears to have crested, its virulence and possible repetition compel us to think anew about the most fruitful responses to group-based hatred in our communities.

Professor Dan Kahan provides us with one of the most provocative recent analyses of community-based responses to hate crimes. ${ }^{2}$ Kahan has sought to apply the insights of legal scholar William Miller to the criminal context, to foster a "progressive appropriation of disgust."3 In particular, Kahan argues that communities should mobilize the emotion of disgust to fight the disgust expressed in hate crimes themselves. He suggests that this

Copyright $\odot 2002$ California Law Review, Inc. California Law Review (CLR) is a California nonprofit corporation. CLR and the authors are solely responsible for the content of their publications.

$\dagger \quad$ Herma Hill Kay Distinguished Professor of Law, University of California, Berkeley, School of Law (Boalt Hall); Professor of Law, Cornell Law School. I am grateful to Susan Bandes, Jack Jackson, and Anna Marie Smith for conversations on the subject of this Essay, and to Tucker Culbertson for his thoughtful comments on an earlier draft. My thanks, as well, to Andrea Ambrose for superb research assistance. Ginny Irving, of the Garret W. McEarney Law Library at Boalt Hall, also provided expert advice and assistance on several aspects of the research.

1. See Mary Leonard, Fighting Terror Domestic Impact: Civil Rights; Arab-Americans Feel Sting of Profiling, Michigan Community Protests Bias and Even Hate Crimes, Boston GloBe, Oct. I9, 2001, at A20 (describing the rise in hate crimes following September II).

2. This view is articulated primarily in two relatively recent works: Dan M. Kahan, The Progressive Appropriation of Disgust, in The Passions of LAw 63 (Susan A. Bandes ed., I999) [hereinafter Kahan, The Progressive Appropriation]; Dan M. Kahan, The Anatomy of Disgust in Criminal Law, 96 Mich. L. Rev. I62I (1998) (book review) (reviewing William IAN Miller, The ANATOMY OF DisGUST (1997)). For a discussion of Kahan's central theses relating to disgust, see infra Part I.A.

3. See Kahan, The Progressive Appropriation, supra note 2, at 63 (stating that his goal "is to redeem disgust in the eyes of those who value equality, solidarity, and other progressive values"). 
approach, which he sees as already emerging among targeted groups and enforcement officials, would provide the best hope of producing the moral or normative realignment necessary to reduce the incidence of these crimes.

In this Essay, I argue that Kahan's approach to hate crimes is deeply flawed. Fighting "disgust fire with disgust fire" is less prevalent as a response by targeted groups than Kahan's analysis suggests. Moreover, its use as a forward-looking strategy founders on its misapprehension of the complex dynamics of hate crimes. Recent research reveals group-based violence to be not a simple expression of hierarchical judgment, but an opportunistic crime, in which perpetrators negotiate a range of status-related anxieties through aggression against socially stigmatized targets. Public expressions of disgust may, in fact, incite potential perpetrators, without addressing the stigmatization that constructs some groups as available targets. A regime of publicly articulated disgust is also likely to produce forms of subjectivity and civic engagement that will corrode the social fabric of the communities in which they are deployed. A better approach uses enhanced sanctions, amplified by expressions of indignation, to draw the lines regarding acceptable conduct, and directs community-based efforts toward eliminating the stigma that creates available targets.

In Part I of this Essay, I set out Kahan's argument, marking, as Kahan does himself, its debt to William Miller's work on disgust. After exploring Kahan's four general theses regarding disgust, I describe his approach to hate crimes as consisting of a descriptive claim, that enforcement officials and targeted groups are already beginning to respond to hate crimes through public manifestations of disgust, and a normative claim, that this strategy will prove uniquely valuable in addressing hate-based violence in our communities.

In Part II, I take up Kahan's descriptive claim, by assessing the responses of two targeted groups: recently targeted Arab and Muslim Americans, and gays and lesbians, who have been a longstanding target of group-based violence. I argue that, occasional rhetoric aside, neither group has sought primarily to "f[i]ght disgust fire with disgust fire" in responding to hate crimes. ${ }^{5}$ The varied strategies used by these groups have, in fact, focused less on the public perception of the perpetrator than on the public stigma associated with the targeted populations. This focus is salient, and appropriate, given the analysis of group-based violence that I prcsent in Part III.

Part III takes on Kahan's normative thesis, concerning the distinctive value of disgust in enforcement against group-based violence. Part III.A.

4. Id. at 69 (characterizing response of gay and lesbian groups to antigay hate crimes and explaining his view of the normatively proper approach).

5. Id. 
considers this claim in light of research on the dynamics of group-based violence. If such violence is, as recent evidence suggests, an opportunistic crime in which perpetrators manage status-based anxieties through violence against socially stigmatized targets, expressions of disgust seem particularly ill-suited to ameliorating these patterns. Part III.B. considers the larger normative goal underlying Kahan's approach to hate crime-the effort to use disgust to recalibrate social hierarchy along more progressive lines-and finds it to be a dubious prospect, particularly in light of the historical analysis offered by Kahan's intellectual mentor, William Miller. Part III.C. returns to the realm of hate crimes to consider the larger social effects of a regime of counterdisgust. I argue that such a regime will likely foster forms of human subjectivity and political engagement about which commumities should be extremely wary.

In the Conclusion, I outline the elements of a more promising approach to group-based violence. While enhanced penalties and public statements mobilizing the more articulate and egalitarian sentiment of indignation can sigual the unacceptable character of group-based violence, community efforts aimed at ameliorating group-based stigma, and generating greater solidarity with targeted groups, will be equally important over the long run.

\section{I}

\section{"Disgust Fire" in the Realm of Hate CRimes}

Kahan's analysis has garnered attention as part of a larger body of work-much of it produced by participants in this Colloquium ${ }^{6}$ - that seeks to reanimate criminal law by harnessing the compliance-inducing force of social norms. Because these norms often produce compliance by triggering "emotions of self-assessment," such as shame and pride, Kahan's work has also intersected provocatively with scholarship exploring the role of the emotions in law. ${ }^{8}$ In recent work, Kahan has begun to narrow a longstanding preoccupation with shame, and its role both in compliance and in alternative criminal sanctions, to a focus on the operation of disgnst in criminal law. Drawing thoughtfully on the account of the emotion provided by William Miller's comprehensive The Anatomy of Disgust, ${ }^{9}$ Kahan seeks to engender a "progressive appropriation of disgnst" in crimmal law.

6. See, e.g., Dan M. Kahan \& Tracey L. Meares, Foreword: The Coming Crisis of Criminal Procedure, 86 GEO. L.J. 1153 (1998); Dan M. Kahan, Social Influence, Social Meaning, and Deterrence, 83 VA. L. Rev. 349 (1997).

7. I take this term from a relatively early and thoughtful work on such emotions: GABRIELE TAylor, Pride, Shame, and Guilt: Emotions of Self-Assessment (1985) (characterizing, distinguishing, and describing the operation of pride, shame, and guilt).

8. For an excellent sampling of recent work in this vein, see THE PAssions of LAw, supra note 2.

9. MILLER, supra note 2. 
Kahan's approach to hate crimes is central to this project. He views enforcement against hate crimes as part of a larger effort to reform "hierarchies based on race, ethnicity, gender, physical and mental handicap [and] sexual orientation." 10 This provides a connection to his target audience of politically marginalized groups and their progressive allies. Structuring his argument around a series of "theses" about disgust drawn from Miller's work, ${ }^{11}$ Kahan explains why the emotion of disgust should animate the enforcement, and public discourse, against hate crimes.

\section{A. Kahan's Disgust Theses}

In undertaking his project to reform hierarchies, Kahan introduces four disgust theses. First, his "evaluative" thesis describes disgust as a cognitive response to an object or practice, rather than as a burst of unreflective affect. The "conservation" thesis argues that disgust, long viewed as a hierarchical emotion, is mobilized even in egalitarian societies, sometimes for the express purpose of challenging existing hierarchies. The "moral indispensability" thesis holds that disgust is a uniquely expressive means of registering moral disapprobation. The "self-delusion" thesis holds that liberals fool themselves by thinking that they can suppress their own feelings of disgust, or prevail against unjust hierarchy without mobilizing them.

The "evaluative" thesis rejects the prevalent notion that disgust reflects a "thoughtless surge of affect." I2 It describes disgust, instead, as an evaluative judgment that a particular object or practice is "low and contaminating, and ... we must insulate ourselves from it lest it compromise our own status." ${ }^{13}$ The cognitive component of disgust, which Kahan traces to Miller's analysis, ${ }^{14}$ makes disgust appropriate in public discourse, and in the judgments about guilt and punishment. This evaluative element

10. Kahan, The Progressive Appropriation, supra note 2, at 65 (quoting MILLER, supra note 2, at 235).

11. Each of the primary works articulating Kahan's view of hate crimes advances a slightly different account of these theses. What follows is my own synthesis, or articulation, of those theses most important to the treatment of hate crimes in Kahan's account of disgust.

12. Kahan, The Anatomy of Disgust in Criminal Law, supra note 2, at 1632.

13. Kahan, The Progressive Appropriation, supra note 2, at 64 (citing MILLER, supra note 2, at 8-9).

14. It is not unequivocally clear that this is a persuasive reading of Miller. Miller seeks to elaborate the cognitive content of disgust as it appears in the moral and political realms and to provide a kind of cognitive translation of the visceral response of disgust that follows from stimuli received through the nose, mouth, or eyes. Yet it might also fairly be said that one of Miller's signal contributions is to connect disgust-even in its political manifestations-with a powerful visceral response. Disgust is politically puissant, Miller argues, because it "puts our bodies behind" our commitments. MILLER, supra note 2, at I8I. Taking Miller's exposition as a whole, it remains unclear that the evaluative aspect of disgust is prior, temporally or in its intensity or importance, to the visceral aspect. 
has also played a role in adjudication related to hate crimes. ${ }^{15}$ It explains, for example, why courts in cases raising the "homosexual panic" defense respond primarily to the plausibility of the assessment entailed in the panic response, rather than to the intensity of the defendant's feelings. ${ }^{16}$

Kahan's "conservation" thesis describes disgust as ubiquitous, virtually inevitable, in society. This is true, he notes, "not only for aristocratic regimes ... but also for egalitarian democratic ones, which are "based less on mutual respect for persons than on a ready availability of certain styles of contempt to the low that once were the prerogatives of the high."'17 The "conservation of disgust" highlights a phenomenon that Kahan finds to be salient: marginalized groups within egalitarian regimes "seek to appropriate rather than annihilate the idiom of disgust, and ... [it] becoines a salient focal point for political contention within socially fluid, pluralistic societies." ${ }^{\text {13 }}$ Kahan sees this effort withm garden-variety political struggles to redefine the relevant social hierarchies. Who, the contending parties ask, deserves the term "disgusting"- "the National Endowment for the Arts for funding sacrilegious art or conservative congressmen for proposing to screen NEA grant applications for offensiveness?"19 $\mathrm{He}$ also sees this struggle to define the disgusting in hate-crime controversies: supporters of hate-crime legislation do not satisfy themselves by arguing for tolerance; rather, they claim to be disgusted by the "twisted," "warped," and "sick"20 behavior of perpetrators.

Kahan initially employs the "conservation" thesis as a descriptive argument: the use of disgust is a political strategy deployed even within egalitarian regimes and by targeted groups and their progressive allies. Yet this thesis also assists Kahan's normative advocacy of disgust by responding to liberals, who insist that communities and enforcement efforts should embrace "theories and styles of argument that are themselves free of disgust and hence free of that sentiment's sad historical association with unjust hierarchy."21 The conservation thesis suggests, first, that some level of progressive appropriation of disgust is already part of the status quo.

15. I will not undertake to challenge the "evaluative" thesis. I agree with Kahan, and with Miller, that disgust is not simply a spasm of affective response, but also entails a coguitive judgment of valuation. I disagree with Kahan about whether this particular form of evaluation has already penetrated the area of hate crimes to the extent that he suggests, and whether it-as opposed to other emotional responses and forms of discourse that entail evaluative judgment-is likely to be the most productive way of responding to hate crimes.

16. Kahan, The Anatomy of Disgust in Criminal Law, supra note 2, at 1634-35. This is true, as Kahan notes, both when judges credit or reject the defense and in both the guilt and sentencing phases of criminal adjudication.

17. Kahan, The Progressive Appropriation, supra note 2, at 64-65 (citing MILLER, supra note 2, at 21).

18. Id. at 65 .

19. Id.

20. Id. at 69 .

21. Id. at 70 . 
This positions liberal opponents of this strategy as moral or emotional outliers, unable to tolerate any expression of disgust, and interested in purging the status quo of its quietly flourishing, disgust-driven hate-crime strategies. Second, because this thesis demonstrates that a commitment to equality results not in the renunciation of hierarchies, but in a competitive struggle to give them new content, it presents liberals who resist disgust as unrealistic. More specifically, this characterization of antidisgust liberals as wrongheaded opponents to an almost inevitably unfolding status quo helps to set up one of Kahan's central normative theses-the "self-delusion" thesis discussed below.

Two additional theses bolster the normative thrust of Kahan's argument. The first is the "moral indispensability" thesis: without the uniquely potent moral vocabulary that disgust provides, we cannot adequately signal that which we find most distinctively blameworthy about vices such as cruelty, or acts signaling extreme forms of depravity. ${ }^{22}$ To make this point, Kahan renders details of a number of grizzly crimes, including some hate crimes, that he sees as impossible to adequately condemn in the idiom of anger or indignation. For instance, Kahan cites the case of Gunner Lindberg, the first offender sentenced to death under a California statute authorizing capital punishment for racially motivated killings, who stabbed a Vietnamese American man more than fifty times at a skating rink to show how easy it could be to "kill a Jap."23 Or, Kahan describes the case of Dennis Beldotti, convicted of the violent rape and murder of a young woman, who asked from prison that the sex toys and pornography with which he committed his crimes be returned to his representatives outside of prison. "What besides disgust," Kahan asks, "can really explain the perception that granting [Beldotti's] request would be wrong? And if nothing else does, what could possibly justify committing ourselves to a regime that quiets so urgent a moral instinct?"24

22. Kahan, The Progressive Appropriation, supra note 2, at 64 ("No other moral sentiment is up to the task of condemning such singular abominations as 'rape, child abuse, torture, genocide, predatory murder and maiming."').

23. Id. at $69-70$.

24. Id. at 69. Kahan does in fact say more about the appropriateness of the court's uitimate response to the Beldotti request:

[T]reating [his request] as if it were no more remarkable than a claim for a stolen wallet ... would have trivialized the unfathomable cruelty of his deeds. Indeed, because the atrocity of his crime consisted largely in the satisfaction he took in defiling his victim, restoring these items to his control ... would have allowed Beldotti ... to continue degrading her after death.... [and] enabling Beldotti to satisfy his tastes would inevitably have made the state itself complicit in his depravity. The only way to avoid being tainted by his request was to throw Beldotti's misogynistic magazines... "in the trash where they belong"rhetorically, if not literally.

Id. at 68 .

However, while this statement explains why the state's decision was appropriate, using the rubric of contamination that is consistent with the idiom of disgust, it does not fully explain why only disgust is appropriate. In fact, his frequent recourse to assertions or rhetorical questions when making the 
More uniquely germane to the hate-crime context, however, is Kahan's final argument, which he describes as the "self-delusion" thesis: liberals fool themselves if they believe they can suppress, or gain by suppressing, a sentiment as vital and protean as disgust. ${ }^{25}$ According to the "conservation" argument, the effort to re-draw hierarchies, and the accompanying disgust that does its more visceral work, is inevitable, even (or perhaps distinctively) in equalizing regimes. Liberals who fail to recognize this risk relegating themselves to a position of naive disadvantage. "[I]f progressives disclaim disgust in their public rhetoric," Kahan argues that

they will more often than not be restraining themselves unilaterally, allowing their adversaries exclusive access to this rich species of expressive capital. To put this point in more concrete and partisan terms, if we give up on enhanced penalties for gay bashing, they will still insist on the Defense of Marriage Act. ${ }^{26}$

In addition, the public renunciation of disgust will not end the sentiment's operation, but will simply "push [it] down below the surface of the law, where its influence is harder to detect."27

"indispensability" argument suggests that only the forceful bodily aversion characteristic of disgust can do justice to our abhorrence of certain crimes.

The insufficiency of this intuitive assertion becomes clear when one considers the alternative raised by Martha Nussbuam: indignation is almost always sufficient to condemn those crimes that Kahan would indict by recourse to disgust. Indignation, Nussbuain explains, involves not the notion of contamination implicit in disgust, but "the idea of a wrong or harm ... whether to the person angered or to someone or something to whom that person ascribes importance." Martha C. Nussbaum, "Secret Sewers of Vice": Disgust, Bodies, and the Law, in THE PASsions of LAw, supra note 2, at 26. Nussbaum argues that indignation is better suited to "ground public action in a society that aims to base its judgments on the public exchange of reasons," $i d$. at 27 , as its logic enables the indignant to explain why the treatment received was undeserved by or inappropriate to the person who suffered it. Nussbaum describes the evil of Beldotti's request not as the threat to contaminate the state with Beldotti's depravity, but as the wrong of injuring and disrespecting the dead, and anyone else who cared about her, by rewarding Beldotti with the instruments of his crime. Id. at 54 .

My point is not so much to characterize Nussbaum's argument as superior to Kahan's, although I, myself, am persuaded by it. It is to observe that whether or not one views disgust as the only emotion capable of doing justice to the atrocity of a crime seems to depend on a number of factors that do not seem to relate to the expressive character of disgust per se, such as one's interpretation of the crime in question (was Belodtti's wrong attempting to contaminate the state with his own depravity or to further injure and demean the dead?) or one's attitude toward the expressive value, in the context of condemnation, of the visceral reaction implicit in disgnst (does "putting one's body behind" one's words effect a more powerful form of condemnation?). Ultimately, these questions may have as much to do with the imterpretation of particular crimes or the temperament of the observer as with the arguments made by Kahan or Nussbaum, although I find Nussbaum's claim for the greater articulacy of indignation $\mathrm{m}$ public settings to be important in arriving at my own preference.

Although I will not focus separately on the "moral indispensability" thesis, my argument in Part III will respond to it indirectly in at least two ways. First, I question the notion that disgust gives us unique purchase on vices such as cruelty. Second, it seems implausible that an emotion capable of wreaking the kind of constitutive havoc I describe in Part III could appropriately be characterized as "morally indispensable."

25. Kahan, The Progressive Appropriation, supra note 2, at 73.

26. Id. at 71 .

27. Id. at 72 . 
Kahan argues that when decision makers are open about disgust, the public can assess the evaluative judgments of high and low, or worthy and unworthy, that animate their sensibilities. ${ }^{28}$ An example of this point was the Texas judge who leniently sentenced a man convicted of murder in a gay-bashing crime. In so doing, the judge noted: "I put prostitutes and gays at about the same level, and I'd be hard put to give somebody life for killing a prostitute." 29 This statement produced a storm of public debate, which culminated in the judge's censure and defeat, and the passage of a statute enhancing penalties for crimes motivated by group-based bias. ${ }^{30}$ This collective assessment of the judge's normative hierarchy would never have been possible had he felt constrained from articulating his disgust.

\section{B. Assessing Kahan's Disgust Theses}

Kahan's analysis leaves several questions open, which is unsurprising given the provocative, exploratory character of his hate-crime thesis and the ambitious scope of his "progressive appropriation" of disgust. Specifically, what follows from conceiving hate crimes as an expression of disgust that communities should fight with the same weapon? To some degree, Kahan's effort to find a contest of disgusts within the present approach to hate crimes obscures the answer to this question. He seenis at times to argue that communities are moving toward their goal of eliminating hate crimes, if we only understand these moves correctly; yet this suggestion seems partly strategic and aimed at putting liberal opponents of disgust on the defensive. Kahan implies at other times that some further expression of disgust would be necessary to implement his approach, though he is less explicit about what that would entail. One possibility is a more uniform approach to enhanced penalties: if enhanced penalties for those who commit bias crimes reflect a community's disgust, perhaps legislatures should authorize them in jurisdictions where they are not currently available. Yet Kahan's ambivalence about whether the criminal-justice system is the vehicle for expressing "counterdisgust," or the forum in which community representatives assess competing disgusts, makes it hard to glean a clear answer, on either enhanced penalties or the role of disgust in mitigation. Kahan lauds the Texas case despite the judge's stark affirmation of the perpetrator's disgust because the clear articulation of competing disgusts permitted the community to weigh them.

Notwithstanding this ambivalence about the role of courts and legislatures, Kahan has a clear view of what his approach entails for progressive opponents of bias-related violence. They should think and talk about hate crimes as manifesting disgust toward the targeted groups. More

28. Id. at 73 .

29. Id.

30. Id. 
importantly, any efforts to secure legislation or other forms of enforcement should aim to express a countervailing disgust for perpetrators. Enhanced penalties themselves see1n necessary but not sufficient to this end, for Kahan repeatedly lauds public statements inanifesting disgust for biasrelated hatred and seeking, more generally, to recalibrate social hierarchies to place perpetrators near the bottom. ${ }^{31}$ Encouraging such articulations, and the shifts in understanding of the crime and its perpetrators that underlie them, is consistent with Kahan's einphasis on criminal law's "expressive" purposes. $^{32}$

I consider the merit of this conceptual and expressive shift in the following sections. In Part II, I assess Kahan's "conservation"-related thesis that targeted groups and their progressive allies are already responding to hate crimes with competing expressions of disgust. In Part III, I evaluate Kahan's normative claim, in particular the "self-delusion" thesis, that progressives are wrong to believe that they can respond to the violent expression of hate without the "powerful rhetorical capital" that disgust provides..$^{33}$ I will also consider a related question, which Kahan does not pose: ${ }^{34}$ whether a regime of dueling disgusts has consequences for the shaping of human subjects or forms of public engagement that should inake us reluctant to embrace it.

\section{II}

\section{Resisting Hate Crimes: Two Targeted Groups Respond}

Can we glimpse, in community-based responses to hate crimes, an emerging regime of competing disgusts? In assessing Kahan's descriptive claim, it may be useful to consider the response to hate-related violence by some targets of hate crimes and their allies. ${ }^{35}$ In this section, I analyze the

31. See, e.g., Kahan, The Progressive Appropriation, supra note 2, at 70 (lauding a public official's disgust-based condemnation of Gunner Lindberg's bias-related killing).

32. See Dan M. Kahan, What Do Alternative Sanctions Mean?, 63 U. CHI. L. Rev. 591, 595-604 (1996).

33. See Kahan, The Progressive Appropriation, supra note 2, at 63.

34. Kahan forecloses this question, to some degree, through the "conservation" thesis. If responses of disgust already mark our present approach to hate crimes, and if they are, to a large degree, inevitable in any social or political order, there would seem to be little point in assessing the potential negative consequences for the shaping of human subjectivity or the forms of political engagement that they produce. More to the point, however, Kahan does not pursue this line of analysis because the form of social constructivism implicit in his norms-based approach to criminal law is peculiarly limited. As I will argue in Part III, his alternative regimes of criminal enforcement are intended to shape the behavior, if not indeed the subjectivity of "them"- the potential offenders who are subject to disgust and sanctions; yet he does not explicitly contemplate the possibility that they also shape the subjectivity of "us"-the ostensibly law-abiding citizens who take part in a particular approach to enforcement.

35. Although it is necessarily incomplete, I consider this examination of target-group behavior more revealing than a survey of jurisdictions that have enacted enhanced penalties for hate crimes, for example. Enhanced pcnalties may reflcct a desire to punish or prevent hate crimes; however, they do not necessarily reflect an expression of disgust at their commission. 
response to hate crimes of two prominently targeted groups: Arab and Muslim Americans and gays and lesbians. Although their responses vary, and emerge from a range of different factual contexts, I conclude that neither group has focused primarily on a strategy of answering "disgust fire with disgust fire." Following this examination, I consider whether the rhetorical evidence to which Kahan points actually supports an interpretation that enforcement officials and other progressive allies of targeted groups have begun to introduce a regime of counterdisgust in answering haterelated violence.

\section{A. Visibility and Knowledge: Arab and Muslim Americans Respond to Hate Crimes}

The wave of hate crimes that beset Arab and Muslim Americans following the attacks of September I1 is by now well known. Within hours of the World Trade Center towers' collapse, virulent anti-Arab messages flooded Arab American websites; angry protesters targeted and defaced mosques; and individuals assumed-correctly or incorrectly-to be Muslim were subject to verbal abuse, physical threats, and violent, sometimes deadly, assaults. ${ }^{36}$ In the month following the terrorist attacks, the American-Arab Anti-Discrimination Committee collected 500 reports of harassment, intimidation, and hate mail, and the U.S. Department of Justice initiated investigations into 170 cases involving killings, shootings, and arson. ${ }^{37}$ Although local and national leaders, including the President, ${ }^{38}$ called repeatedly for calm and tolerance, fear and vigilance filled the days for many of Middle Eastern origin or Muslim faith. Parents agonized over whether it was safe to send children to school, women debated the consequences of wearing hijab-the traditional Muslim head covering-in public, and many Arab Americans remained in their homes, out of sight. ${ }^{39}$

36. See, e.g., Janelle Brown, Anti-Arab Passions Sweep the U.S., SAlon.com, Sept. 13, 2001, at http://www.salon.com/news/feature/2001/09/13/backlash (last visited Apr. 27, 2002) (describing a range of attacks on Arab and Muslim Americans); Leonard, supra note 1 (describing hate crimes and reaction in large Arab American community of Dearborn, Michigan); Tatsha Robertson, America Prepares Domestic Impact: Jersey City; Diverse City in Fear, Distrust, Boston Globe, Oct. 7, 2001, at A19 (describing anxiety and ambivalence toward Arab Americans in Jersey City, New Jersey).

37. Leonard, supra note 1; see also U.S. DeP'T OF JUSTICE, CiviL. RIGHTS Div. NAT'L ORIGIN WORKING GROUP, at http://www.usdoj.gov/crt/nordwg.html (last visited Apr. 27, 2002) (collecting data about violence against various groups as defined by national origin, including Arab Americans and Sikhs); U.S. Dep'T OF Justice, Civil Rights Div. ENForcement \& Outreach, at http://www.usdoj.gov/crt/legalinfo/discrimupdate.htm (last visited Apr. 27, 2002).

38. Arab American leaders widely praised President George W. Bush's visit to a Washington, D.C., mosque in the days following the attacks. See, e.g., Mei-Ling Hopgood and Ahan Kim, Increasingly Savvy Arab and Muslim Activists Reacted Quickly to Attacks, Cox News SERvice, Oct. 5, 200l, at http://www.accessatlanta.com/ajc/islam/1006influence.html (last visited Apr. 27, 2002) (describing George W. Bush visit to mosque and Arab American leaders' assessment of effect of positive intervention by the President and Congress).

39. See, e.g., Jeannette Batz, Is It Safe Yet? For Muslims in St. Louis, Politics Gets Personal as Fear Dominates Their Lives, Riverfront Times (St. Louis, Mo.), Oct. 10, 2001, available at 
But withm a short time, Arab and Muslim American communities began to organize and to respond. ${ }^{40}$

Their efforts to date suggest two related strategies, neither of which involved subjecting their assailants to expressions of disgust. ${ }^{41}$ The first response has been a traditional civil-rights strategy. Galvanized by the growing political savvy of Arab American advocacy organizations, Arab American groups have begun gathering information, raising consciousness about hate-related attacks, and calling on the government for support and protection. Groups developed a protocol for the reporting of hate crimes, so that Arab American organizations and communities could keep government, enforcement officials, and the public informed about the threats facing their members. ${ }^{42}$ Organizations also lobbied the White House and the Department of Justice for public statements of support and enhanced enforcement efforts. ${ }^{43}$ Increasingly warm relations between the Republican

http://www.rftstl.com/issues/2001-10-10/feature.html (last visited Apr. 27, 2002) (describing fear and vigilance in Muslim American communities); King Kaufman, Stand Beside Her, SALon.com, Oct. 22, 2001, at http://www.salon.com/mwt/feature/2001/10/22/women_of_cover/index.html (last visited Apr. 27, 2002) (describing anguished choices facing anxious Arab and Muslim Americans, but also increasingly supportive community response).

40. See infra notes $42-53$ and accompanying text.

41. A question preliminary to this analysis might be whether crimes committed against Arab and Muslim Americans following the September 11 attacks should be placed within the category of hate crimes that Kahan considers to be motivated by disgust. One might argue that the crines committed against Arab Americans after September 11 were distinct in that they were motivated by anger or fear, rather than group-based disgust. Although 1 do not doubt that virtually all Americans, including perhaps the perpetrators of these crimes, felt fear or anger after September 11, this does not, to my mind, negate the element of group-based, hierarchical thinking that animated these acts. The impulse to generalize one's fear and antagonism from the September 11 hijackers (a small number of religious extremists of Middle Eastern origin) to anyone practicing the Muslim faith or appearing even vaguely Middle Eastern in origin (including South Asians and Sikhs), indicates a potent inclination to group and stereotype people with these characteristics. A similar point was made by Justice Murphy in his dissent in the Korematsu case: the fact that America was under attack by the Japanese (and military officials were therefore motivated by a concern for security) did not mean that the internment of Japanese Americans was untainted by discrimination. Indeed, the facts that every Japanese American was inplicitly suspected of disloyalty and that the government felt incapable of distinguishing annong meinbers of the group on an individual basis seemed to Justice Murphy to be strong evidence to the contrary. See Korematsu v. United States, 323 U.S. 214, $235-43$ (1944) (Murphy, J., dissenting).

In the case of the crimes against Arabs or Muslims, as in Korematsu, fear or anger may provide the immediate incitement, but it acts upon an existing reservoir of group-based, hierarchical feelings and beliefs. As I explain more fully in Part III, I think it is an oversinplification to characterize the coinplex array of self- and "other"-regarding emotions and judgments that animate group-based violence simply as "disgust." But I consider hierarchical judgments about the relative value of various groupsjudgments that Kahan would probably characterize at least in part as "disgust"- to be anong this array of emotions and judgments, in the anti-Arab attacks of last fall as well as in more conventional hate crimes. Because Kahan would describe such judgments at least in part as "disgust," it seems plausible that he would characterize recent crimes against Arab Americans as motivated by disgust.

42. See Hopgood \& Kim, supra note 38.

43. A coalition of Muslim American groups had endorsed George W. Bush prior to the election, and he received inore than $70 \%$ of the Muslim vote. A few leading Arab American activists, such as Arab American Institute Chairman George Salem, had been active in the Bush cainpaign. Id. 
administration and Arab American organizations sometimes assisted this effort. $^{44}$

A second response, however, emerged in a more widespread, grassroots fashion, in a range of communities. Arab and Muslim Americans began to emerge from their homes and to reach out to others in their communities. This effort, which might be described as an "enlightenment" strategy, ${ }^{45}$ sought to put a human face on an identity that had become demonized and to increase knowledge about Muslim religious practices and teachings. Numerous Muslim American organizations encouraged this approach. For example, the Council on American Islamic Relations circulated a "mosque open house kit," which featured a form press release and suggestions such as "inform your guests of mosque etiquette" and "make sure the bathrooms are spotless." 46 Non-Muslims also abetted this response by showing support for, and seeking contact with, their Arab and Muslim American neighbors following the first anti-Arab response. ${ }^{47}$ Yet in an effort more spontaneous than hierarchically orchestrated, Arab and Muslim Americans throughout the country began to introduce themselves, literally and figuratively, to their neighbors and to engage in impromptu consciousness-raising about the practices and tenets of Muslim faith. ${ }^{48}$

44. Id.

45. I use the term "enlightenment" both because targeted groups sought to enlighten potential perpetrators about their group identity and practices and because the strategy reflects an understanding, attributable to liberal values stemming back to the Enlightenment, that group-based prejudice is essentially irrational or grounded in ignorance, and it can be dispelled by greater knowledge.

46. Id.

47. No doubt reassuring to a nation attacked from without, and startled by a spasm of violence from within, the national and local media pervasively covered this upsurge of neighborliness and intergroup concern during the weeks following September 11. See, e.g., Elizabeth Bell, Long-Term Relationship with Its Muslim Community May Help Lodi Weather the Recent Spate of Fear and Suspicion, S.F. Chron., Oct. 21, 2001, at A27 (describing "Breakthrough Project," a collaborative effort by the mayor, police, and local groups to generate intergroup contact and understanding among Muslims and other community members); Janice L. Habuda, Understanding of Arab/Muslim Culture Urged, BuFfalo News, Oct. 17, 2001, at B3 (describing U.S. Government-facilitated efforts by Buffalo groups to learn more about the practices and beliefs of their Muslim neighbors); Kaufman, supra note 39 (describing emergence of "accompaniment" movement in St. Louis, which offers nonMuslim escorts to prevent harassment of Muslim women who appeared in public in hijab); Caryle Murphy, For Muslims, Benevolence Prevails over Backlash, WASH. Post, Oct. 6, 2001, at Al (describing outpouring of community support for Muslim Americans after vandalization of Islamic Bookstore in Alexandria, Virginia, following September 11 attacks, and other, similar supportive gestures).

48. See, e.g., Mark Sullivan, Muslims Try to Speak Out About Faith; Islamic Families Fan Out in Area to Correct Misunderstandings, Boston GloBe, Oct. 21, 2001, at 1; Anand Vaishnav, Floodlights Shine on Mosques; Muslims Invited to Share, Teach, Boston GLoBE, Oct. 9, 2001, at B1; Jeffrey Weiss, Muslim Holy Month Earns Schools' Respect; Out of Tragedy, Lessons About Ramadan Grow, Dallas Morning News, Nov. 16, 2001, at 1A (describing Ramadan as occasion for Muslim outreach this year and noting its inclusion in public-school discussions as evidence of successful outreach that has already occurred); see also Leslie Berestein, Hate Crimes Stir Fear in Islamic Community, L.A. TIMEs, Dec. 4, 1994, City Times at 3 (describing similar outreach effort in face of anti-Arab or antiMuslim response to Gulf War and acts of terrorism in Middle East). 
Part of this effort simply involved making themselves known-im human and tangible terms - to neighbors who might vilify them in the abstract. As the President of a Massachusetts Islamic center noted: "If you don't know something or don't understand something, you usually are afraid of it. Once you get to know something, you understand it more." $\$ 49$ Or, as another Arab American activist stated, "[ $[t]$ he average American is meeting Muslim or Arab Americans and discussing [his] stereotypes."50 Perhaps, more importantly, however, such outreach has aimed to educate the wider public about the Muslim faith. The identification of the perpetrators in the September 11 attacks as "Muslim fundamentalists" or "Islamic extremists" created confusion in the minds of many Americans about whether the Muslim faith permits or compels its adherents to commit violent acts. Moreover, this kind of misapprehension may have been the primary association some Americans had with the religion, knowing little about the practices or belief systems of observant Muslims.

Some Muslim Americans felt implicated in this ignorance, seemg it as a consequence of their often self-imposed distance from the American mainstream. As one president of a local American Muslim Council put it, the fact that public officials and employees "do not fully understand ... the issues or sense of duty of Muslims ... partly may be our own failing." Others felt that, regardless of the reasons for its emergence, a confusion capable of fostering violence demanded swift attention. Among the points stressed im meetings and open-mosque sessions has been the essential peacefulness of Islamic teachings. As the media-relations director for the Islamic Society of Boston explained: "We are trying to differentiate Islam as a religion and how some people are using Islam for political rather than religious aims.... Islam condemns terrorism, condemns the killing of innocent people.... Our religion is one of benevolence, of peace, of justice." 52 Other sessions, often structured as interreligious dialogues, have analyzed the teachings of the Qu'ran on women, justice, and other questions, or have surveyed the details of daily and seasonal religious practices that observant Muslims undertake. ${ }^{53}$

A striking feature of both of these responses (but particularly the second) is their distance from any rhetoric or conceptualization grounded in disgust. The civil-rights strategy has been pragmatic, rather than expressive. It has sought to enhance the security of Muslim Americans with little or no rhetoric-contemptuous or otherwise-about the character of their assailants. To the extent that this civil-rights strategy is associated with an

\footnotetext{
49. Vaishnav, supra note 48.

50. Hopgood \& Kim, supra note 38.

51. Habuda, supra note 47.

52. Sullivan, supra note 48.

53. See supra note 47 and accompanying text.
} 
emotional response, it is one of indignation-a demand for support by the affronted, and appropriately entitled, citizen - rather than disgust. The outreach strategy, however, goes further to offer at least an implicit, and sometimes an explicit, account of those who commit violence against Arab and Muslim American communities. This strategy characterizes perpetrators as fellow citizens whose lack of knowledge makes them vulnerable to fear, stereotype, and anger. Thus, the outreach strategy focuses on face-toface contact, which humanizes, and the provision of information, which dispels potentially threatening ignorance, as the best means of handling this kind of opponent. Moreover, in some public statements, Arab Americans have embraced a rhetoric that denounces hate and, presumably, related sentiments such as disgust, as the instruments of the terrorist enemy. One of the initial advertisements, produced by Brokaw, lnc. of Cleveland, in conjunction with the Arab American Institute and the Ad Council, shows the new skyline of New York City, with a running message that appears first in the foreground and then gradually fills in the back, to form two phantoin towers. ${ }^{54}$ The last lines of that message are: "Hate has taken enough from us already. Don't let it take you." 55 This explicit renunciation of a recourse to hate, and the larger "enlightenment" strategy that has accompanied it, seems far closer to the position of liberal opponents of disgust than to the disgust-based view that Kahan advocates.

While fascinating and revealing, the position of Arab and Muslin Americans following September 11 might also be describcd as sui generis. The distinctively perilous position of these comparatively recent immigrants in the context of an unprecedented domestic attack, and the implicit mandate of coalescence at a time of war, nay seriously restrict the conceptual and rhetorical avenues available to Arab and Muslim American groups for opposing hate crimes. This in no way detracts from the committed and resourceful character of their response; yet, it suggests that it may be useful to supplement this examination with a look at a group that has been a more longstanding target of hate-related violence, delivered under less

54. Arab American Institute, Public Service Announcements, Video: Americans Stand United, available at http://www.aaiusa.org/psa.htm.

55. Id. This theme is also evoked in some of the narratives relating to genocide. See MARTHA Minow, Between Vengeance and Forgiveness: Facing History After Genocide and Mass Violence (1998); see also Martha Minow, Institutions and Emotions: Redressing Mass Violence, in THE Passions of LAw, supra note 2, at 265-84. Jadranka Cigelj, a victim of ethnic cleansing in Bosma, describes the way that a framework of legal accountability helped to extricate her from feelings of hatred, which she ultimately came to associate with her oppressors:

When you think of a 15-year-old girl whose entire world was destroyed... when you think of how her youth was stolen and how she was turned into a wounded animal, you realize that what is important is to work toward a way to hold these people responsible and punish them. Then one day you wake up and the hatred has left you, and you feel relieved because hatred is exhausting, and you say to yourself, "I am not like them." 
extraordinary circumstances, and that has responded with a variety of conceptual and rhetorical strategies.

\section{B. Plural Strategies: Gays and Lesbians Respond to Hate Crimes}

Gays and lesbians are familiar targets of hate crimes. Responding to this victimization has been a focus of debate and strategizing, within a varied range of advocacy organizations, for several decades. This more extended history of response reveals a more plural approach to the perpetration of group-based violence, which overlaps to some degree with the experience of Muslinn Americans. Yet here, as well, there is little indication that disgust has been a central theme in the groups' public response.

The "enlightenment" strategies of contact and education that have characterized the Muslim community in recent months have been pivotal responses for gays and lesbians as well. ${ }^{56}$ One segment of the gay-andlesbian community has sought first and foreinost to increase contacts and interactions between meinbers of their community and the straight community. Thus, the act of coming out-like the wearing of hijab or participation in daily prayers for Muslims - is frequently cited as a transformative act by exposing many, who might otherwise remain ignorant or fearful, to a human being who can displace prevailing stereotypes. As a member of San Francisco's Community United Against Violence ("CUAV") explains, coming out lets "other people see all of who we are," and it also increases the chances that straight people will get to "know[] somebody well who is lesbian or gay," a development capable of "chang[ing] how heterosexual people think." $" 57$

Beyond the contact achieved through the coming-out process, some advocates endorse outreach and education programs for curtailing groupbased violence. ${ }^{58}$ Such advocates target education both outside and inside the gay-and-lesbian community. Educating the outside world entails demystifying homosexuality and raising consciousness about the occurrence and incidence of gay bashing. Of particular value is training public employees, froin police to subway drivers; this education aims not only to prevent attacks, but also to facilitate professional care and service when violence, or prospective violence, makes it necessary. ${ }^{59}$ For those inside the

56. For an in-depth look at one gay-and-lesbian advocacy organization that employs a set of enlightenment strategies, see Gregory M. Herek, The Community Response to Violence in San Francisco: An Interview with Wenny Kusuma, Lester Olmstead-Rose and Jill Treagor, in HATE Crimes: Confronting Violence Against Lesbians and Gay Men 241 (Herek et al. eds., 1992) [hereinafter HATE CRIMEs].

57. Id. at 258 (statement by Jill Tregor).

58. Id. at 243-45 (statements by Jill Treagor and Wenny Kusuma).

59. As Jill Tregor of CUAV states: "We say to [people], 'We hope you're not homophobic. But here, bottom line, is what we expect from you as professionals when you're dealing with us." Id. at 243. 
community, education aims to end denial and evasion: advocates explain the continuing need for vigilance and teach gays and lesbians the best ways to protect themselves against violence. They also make clear that, should violence occur, reporting is safe and necessary. ${ }^{60}$

As targeted violence has continued, some gay-and-lesbian groups have become increasingly dissatisfied with the response of lawenforcement officials. They also have become impatient with the enlightenment strategies of contact and education. Fueled by the energy and activism of such groups as ACT UP, ${ }^{61}$ Queer Nation, ${ }^{62}$ and Lesbian Avengers, ${ }^{63}$ they have sought to develop new ways of addressing hate crimes. Some of these strategies have been described under the rubric of "bashing back." 64 However, while many strategies involve a more resistant, pro-active approach to group-based violence, fiercely demanding greater accountability from law-enforcement officials and media representatives, and training individuals physically to defend themselves and to intervene on behalf of others, these strategies do not entail the expression of disgust for perpetrators. Individual participants may feel disgust for perpetrators, and some have expressed it in venues unrelated to their enforcement or activist efforts. ${ }^{65}$ But manifesting such disgust is not a part of the activist efforts of these groups.

Some groups have focused on identifying hate crimes as hate crimes when enforcement officials have been reluctant to so label them, and mainstream media have declined even to report them. ${ }^{66}$ The Lesbian Avengers, for example, have combined innovative direct-action demonstrations with the nore conventional, behind-the-scenes lobbying of public officials and the press, to place officially on record instances of violence against

60. See id.

61. For a provocative discussion of the strategies of ACT UP (AIDS Coalition to Unleash Power), particularly in realm of graphic arts, see Douglas Crimp, Art Acts Up: A Graphic Response to AIDS, Out/LooK, Summer 1990, at 23-30. See also AIDS: Cultural Analysis, Cultural Activism (Douglas Crimp ed., 1988).

62. For an introduction to the strategies, sensibilities, and potential limitations of the Queer Nation Movement, see Allan Berube \& Jeffrey Escoffier, Queer/Nation, OuT/Look, Winter 1991, at 13; Queer: Interviews by Steve Cosson, Out/Look, Winer 1991, at 14; Alexander S. Chee, A Queer Nationalism, Out/LooK, Winter 1991, at 15; Maria Maggenti, Women as Queer Nationals, Out/LooK, Winter 1991, at 20. See also Michael Warner, The Trouble with Normal: Sex, Politics, And THE ETHICS OF QUEER LIFE 41-80 (1999) (contrasting strategies and self-understandings of mainstream gay-rights movement with those of queer activists).

63. For an illuminating glimpse into the goals and strategies of the Lesbian Avengers by one of their cofounders, see Sarah Schulman, My American History: Lesbian and Gay Life DuRing THE REAGAN/BUSH YEARS 279-319 (1994).

64. Cf. Chee, supra note 62, at 15 (using "Queers Bash Back" to describe innovative direct-action tactics of the Queer Nation movement).

65. See, e.g., Michael Collins, The Gay-Bashers, in HATE CRIMES, supra note 56, at 191.

66. See Schulman, supra note 63 , at $260,263,286$ (describing fire bombings and arsons targeting gays and lesbians in Salem, Oregon, and Tampa, Florida, which police initially refused to classify as hate-related violence and which initially received virtually no media coverage). 
lesbians and gay men. In the fall of 1992, for example, the group sought to publicize the murder by firebombing of a Black lesbian and a gay man in their home in Salem, Oregon. ${ }^{67}$ This firebombing occurred in the heated atmosphere surrounding the consideration of ballot Proposition $9,{ }^{68}$ a strong antigay measure; yet, the police failed to characterize it as a hate crime and the national press did not cover it.

The Lesbian Avengers sought to identify and publicize this crime through two direct efforts. The first was the creation of a large shrine to these victims in the West Village in Manhattan; an opening ceremony was followed by a vigil that extended from Halloween to Election Day. The second was a torch-lit march, staged without a permit, that proceeded down Fifth Avenue during rush hour. Armed with posters saying, "Do Not Let Thein Rest in Peace," the marchers converged on Rockefeller Center, where they reconstructed the West Village shrine, burned copies of the Oregon (and similar Tainpa) ordinance, and held a rally. Following these actions, which were supplemented by persistent efforts to contact public officials and representatives of the media, the New York Times and New York Post ultinately covered the murders in op-ed pieces. ${ }^{69}$ Unconventional and outspoken as these actions were, they were not aimed at expressing disgust, or any other elnotion, toward the perpetrators of the crime. Although the rallies featured angry speeches, including at least one pledge to avenge these deaths, ${ }^{70}$ such anger was directed toward a failure to cover and treat the crime as hate-related violence, and toward discriminatory policies such as Oregon's Proposition 9.71

Other groups have focused on self-help efforts aimed at making the streets safer. To this end, gay-and-lesbian street patrols have sprung up in many metropolitan areas. ${ }^{72}$ Some of these are "watchdog" groups that seek to spur inore effective responses from the police by calling them when a bashing is threatened or in progress. ${ }^{73}$ Others are "imterventionist" groups who trani members in self-defense and prepare them to intervene without

67. Id. at 263 .

68. For a discussion of Oregon's Proposition 9, and the tension and anti-gay violence it engendered before its (narrow) defeat, see ScHULMAN, supra note 63, at 263-64.

69. Id. at 260-64 (account taken from Schulman's book). Schulman describes a similar effort waged by the Lesbian Avengers in response to an arson incident in Tampa, Florida, which resulted in the mayor holding a press conference with members of the Lesbian Avengers, at which she decried hate crimes. See id. at 278.

70. Lesbian Avenger Marlene Colburn stated, "We, lesbians and gay men, have no more cheeks left to turn, so we will avenge these murders by any means we see fit." Id. at 264 . There is, however, no record of any Lesbian Avenger having undertaken violent action in response to these murders.

71. Oregon's Proposition 9 was ultimately defeated by a narrow margin. See id. at 264.

72. Sara Miles, The Fabulous Fight Back: On the Streets After Dark to Confront Gay Bashers, Out/Look, Summer 1992, at 58 (describing street patrols in San Francisco, New York, Seattle, Boston, Los Angeles, Sacramento, Houston, and Chicago).

73. See id. (describing watchdog groups in New York's West Village and Sacramento). 
weapons in impending or ongoing bashing incidents. ${ }^{74}$ Even the most aggressive of these groups, however, are conspicuous in their attempts to avoid baiting, expressions of prejudice, or other manifestations of disgust in their patrollimg activities. The San Francisco Street Patrol's rules state that among those actions that may result in expulsion are "The WRONG ATTITUDE (psychopathic desire to stomp nazi skinheads, or the people who rip down flyers or homeless or straights or anyone else who rubs you the wrong way).... Inability to withstand verbal abuse.... Racial or sexual prejudice.... Escalating verbal confrontation...."75 In addition, patrol members, as they speak among themselves, are instructed to refer to perpetrators or prospective perpetrators as "mutants," a term chosen by the Guardian Angels for its comparatively neutral "sci-fi ring," which aims at preventing patrollers from slipping into race, gender, or ethnic epithets in the heat of battle. ${ }^{76}$

74. See id. (describing interventionist groups in New York's East Village, San Francisco, and Seattle).

75. Id. at 57 .

76. Id. at 58. One might question whether the Street Patrols' use of the term "mutant" actually represents an effort to refrain from public expressions of disgust for perpetrators. This is a point worth considering: surely referring to someone in a public statement as a "mutant" would convey derogation if not dehumanization; and, it might have been possible to avoid both group-based epithets and any hint of derogation through the use of a term like "perps." However, I think there are several reasons why the use of this term does not place the Street Patrols in the category of fighting disgust with disgust. The first has to do with the context from which the word is taken: the Guardian Angels, from whom the Street Patrols borrowed the term, describe it as having a "sci-fi ring." In science fiction, the term "mutant" may be viewed as more clinical and less derogatory than in popular parlance (much as the term "alien," when used in Star Trek, would have a more descriptive, less pejorative resonance than the same term used as an epithet in conversation). Second, and more importantly, the term is imtended primarily for informational communication among patrollers, about the location or actions of potential perpetrators, for example. It is not used in public statements that register the kind of assessment or affect regarding perpetrators that Kahan recommends.

This observation leads to a third point about the difference in assumptions implicit in coded private and explicit public expressions of disgust. Even if we were to assume-which I am disinclined to dothat the term "mutant" was chosen because of the hostile or contemptuous attitude it conveys toward its subject, rather than for the more neutral or positive reasons professed by the Guardian Angels and Street Patrols, the way in which this attitude is contained and directed by the use of the term would seem to reflect a judgment about the public expression of disgust that is different from Kahan's own. Using a term with potentially pejorative connotations might be seen as reflecting the groups' recognition of a limited version of Kahan's "conservation" thesis: even progressives committed to equality may sometimes feel the emotions of disgust or contempt. Gays and lesbians claiming equality might feel anger, even contempt, for those who assail their efforts under cover of darkness by means of physical violence. Emotions that tend to belittle-literally, to make small-these potential adversaries may be particularly likely to arise when group members are girding themselves to confront the violence of these adversaries on the street. Yet individuals or groups who experience such feelings (a descriptive matter) must still decide whether and how to act on them (a normative matter). Using a partially neutralized term in the limited context of intragroup communication aimed at combating violence would seem to reflect a rejection of Kahan's more important, normative "indispensability" and "selfdelusion" theses. This use would tend to suggest a view that, far from representing unparalleled expressive capital, public iterations of disgust are inflammatory and inarticulate: where such unproductive, if sometimes inevitable, sentiments arise, it is preferable to vent and channel them through partially coded, intragroup exchanges, than to give them voice in public dialogue. 


\section{A Nascent Regime of Counterdisgust?}

The experiences of both Arab and Muslim American and gay-andlesbian communities cast serious doubt on Kahan's claim that progressive forces opposing discrimination have already begun to introduce a regime of counterdisgust in responding to hate crimes. Even at their most besieged or most innovative, these groups have noticeably refrained from public expressions of disgust toward perpetrators. These examples suggest that targeted groups may find public expressions of disgust impossible, if they are acutely besieged; counterproductive, if their goal is to achieve greater contact and communication with potential perpetrators; or largely beside the point, if their strategy is direct action, aimed at raising public awareness or making the streets safer. In fact, their strategies, considered in the aggregate, seem to focus less on the public perceptions of perpetrators than on the relationship between perpetrators' acts and the attitudes within communities that create available targets. This focus is consistent with what research has begun to uncover about the dynamics of group-based violence, as I will make clear in Part III. But it suggests that the articulation of disgust may be a kind of expressive luxury, available primarily to those who are not theinselves targets of violence, or to those who are not involved in long-term strategies aimed at producing change.

This hypothesis seems to be borne out by the examples Kahan cites to support his theses, in which articulations of disgust have infused in the rhetoric of opponents of hate crimes. These statements come primarily from enforcement officials charged with investigating or adjudicating these crimes. On close examination, however, these expressions seem too unreinarkable in their content, and too equivocal in their meaning, to provide strong support for Kahan's descriptive claim.

Kahan's examples come largely from the fields of race, gender, and antigay violence, areas calculated to appeal to his target audience of progressives uneasy about the invocation of disgust. They are typified by the statement of the chairman of the Orange County Human Relations Commission who observed of Gunner Lindberg's stabbing of a Vietnamesc American at a skating rink, that "[t] here's no question this is a sick act of a really troubled mind."77 Another example is the case of Beldotti $v$. Commonwealth, ${ }^{78}$ in which a prisoner convicted of a grizzly rape and murder sought the return of certain sex toys and other paraphernalia with which he had committed the crime, to his representative outside of prison. ${ }^{79}$ The

77. Kahan, The Progressive Appropriation, supra note 2, at 70.

78. 669 N.E.2d 222 (Mass. App. Ct. 1996).

79. While it does not appear that Beldotti was prosecuted as a hate crime, it might well be considered as such, given that it involved the violent rape and murder of a young woman, implemented through the use of violent pornography bearing such titles as Tamed and Tortured and Tortured Ladies. See Kahan, The Progressive Appropriation, supra note 2, at 67 . For further discussion of Beldotti, see supra note 24 and accompanying text. 
state's attorney argued that the materials should "be thrown in the trash can where they belong. This has nothing to do with free expression. It has to do with the degradation of a young woman by a depraved individual." ${ }^{\text {" }}$ It is clear that such statements depart, to some degree, from a traditional liberal position that eschews public proclamations of contempt. But whether they herald the establishment of a new approach-particularly one potent enough to reshape public sensibilities and seize the attention of (potential) perpetrators-may be doubtful.

First, it is not obvious in these cases that the statements reflect expression of disgust. As Martha Nussbaum has observed, the state's reaction in Beldotti could just as easily be seen as an expression of anger or indignation. Outrage, which Nussbaum treats as synonymous with indignation, is an appropriate reaction to this case because it

expresses the idea that it is unreasonable and wrong to reward Beldotti in just that area where he should be most severely punished. Such a reward would not only be astonishing... it would be a profound injury and disrespect to the dead, to anyone who cares about her, and to society itself. 81

Moreover, the formal legal argument by the Commonwealth invoked both of these emotions and more, stating that surrendering the requested items "would justifiably spark outrage, disgust, and incredulity on the part of the general public." 82 When an enforcement official invokes disgust as one among several emotions appropriate to a case, it is not clear that disgust is effecting the normative realignment or doing the deterrent work that Kahan ascribes to it.

Furthermore, as Kahan's conceptual mentor William Miller observes, there is a distinction between the "idiom of disgust" disgust itself. One of the hallmarks of disgust is its visceral character; it is a powerful urge, often accompanied by physiological manifestations such as a distinctive facial expression or a sensation of nausea, to rid oneself of something perceived as low or contaminating. Language invoking the "idiom of disgust" seeks to appropriate some of the energy associated with this visceral response without necessarily evoking or inducing it. ${ }^{84}$

80. Patricia Nealon, X-Rated Materials Held by Court Sought, Boston Globe, Apr. 2, 1992, at A21 (quoting the district attorney).

81. Nussbaum, supra note 24, at 54 .

82. Beldotti, 669 N.E.2d at 225.

83. Miller introduces the "idiom of disgust" in The ANATOMY of Disgust, supra note 2, at 17981.

84. Miller notes "how hard it is, in normal conversation, to give voice to moral judgments without having recourse to the idiom of disgust." Id. at 180 . He adds: "About persons and actions we say ... things like these: He gives me the creeps. He makes my skin crawl. Yuck! That makes me want to puke.... In a higher register we speak of vile, odious, abhorrent, and loathsome characters and dceds." Id. Yet it seems clear, particularly by reference to the first example, that not all of the persons 
Compare, for example, the verbal gesture toward disgust cited above with the genuine article as expressed in Hitler's Mein Kampf: "Was there any form of filth or profligacy, particularly in cultural life, without at least one Jew involved in it? If you cut even cautiously into such an abscess, you found, like a maggot in a rotting body, often dazzled by the sudden lighta kike!"85 It seems unlikely that a resort to such tired clichés as "sick" acts, "troubled" minds, or even "depraved" individuals, would be sufficient to arrest the attention of the public, let alone to transform its conception of hate criminals or to put perpetrators on notice that their status had been decisively altered.

More importantly, however, it is not clear that a statement such as that of the Orange County official was actually meant to do the political heavy lifting suggested by Kahan. In the realm of disgust, this kind of mild prosaic talk is cheap and equivocal. Indeed, we can hypothesize several reasons for a speaker to articulate such disgust. For instance, making an easy, verbal gesture of disgust can merely sigual-in an understated, liberally palatable way - one's disapproval of a perpetrator. But it could also mean a range of other things. Oona Hathaway has demonstrated that, in the field of international human rights, siguing a treaty or convention does not always signal a country's intent to enforce the specified norms. ${ }^{86}$ Indeed, some signatories are among the worst offenders in any particular instance, raising the inference that they sign as a means of reducing international pressure, buying a little time or space to pursue contrary objectives with a cheap declaration. Similarly, a pat declaration of contempt for a racial-hate criminal might serve an analogous function for an official with a vulnerable record on the vindication of civil rights.

Another explanation for such statements is that they serve psychological, more than political, purposes. As Martha Nussbaum has argued, an expression of disgust may be a vehicle for distancing oneself from an act or sentiment in which one may be personally implicated. ${ }^{87}$ An official might assail as "sick" an instance of racial violence in order to distinguish the subtler acts of racism in which he participates himself. The potentially selfdeluding sense of distance facilitated by disgust, Nussbaum concludes, makes the emotion suspect in the context of public discourse.$^{88}$ It also means that expressions of disgust, particularly when they are as casual as those cited by Kahan, may be unreliable indicators of the actual sentiment and its operation.

or acts described by reference to the idiom of disgust actually invoke the visceral sensation in the speaker.

85. Adolf Hitler, Mein KaMpf (cited in Nussbaum, supra note 24, at 19).

86. See Oona Hathaway, Do Human Rights Treaties Make a Difference?, 111 YALE L.J. 1935 (2002).

87. Nussbaum, supra note 24 , at 50-52.

88. Id. 
Thus, the descriptive portion of Kahan's thesis is vulnerable to criticism in several respects. An examination of the strategies of two prominent targeted groups suggests that at least some groups cannot, or will not, have recourse to the kind of disgust-based response that Kahan describes as emerging under the reluctant gaze of liberal critics. Their responses, albeit varied, suggest a different focus: an effort to revise public attitudes not toward perpetrators but toward their potential targets. Moreover, two of Kahan's own examples of such emergence, Lindberg and Beldotti, are inconclusive, as they seem fatally muted and equivocal in their import. Ultimately, the descriptive argument, and the "conservation" thesis at its core, seems unable to do the work that Kahan has assigned to it, in the structure of his argument as a whole. It becomes more difficult for him to argue, therefore, that liberal critics are outliers or holdouts in a regime of counterdisgnst that is already taking shape. If we are, indeed, to have such a disgust-based regime, it will be necessary to create it; and to create it, we will have to be persuaded of its normative advantages. For this reason, I now turn to the merits of Kahan's normative argument.

III

\section{Constructing a Regime of Disgust}

Kahan's resort to disgust in the realm of hate crimes can be justified if disgust is, in fact, a uniquely powerful species of expressive capital in the struggle against bias-based violence, and if this expression produces no threatening social consequences as it moves toward its goal. As I will demonstrate in this section, both of these assumptions turn out to be deeply problematic.

\section{A. Enforcement Effects of Disgust}

\section{Disgust and the Perpetuation of Hate Crimes}

Does disgust provide unique advantages in curtailing group-based violence? Kahan's view, like much criminal work that seeks to enlist the force of social norms, is premised on the notion that applying specific, noncarcera ${ }^{89}$ disincentives can reduce criminal activity. In particular, the resort to disgust seeks to produce a sense of shame or humiliation in the (prospective) offender that will decrease, or deter him from undertaking, the targeted behavior. But this strategy is, in turn, based on an understanding of group-based violence that is itself reductive or incompletely elaborated. A fuller appreciation of what research has begun to reveal about the nature and causes of group-based violence suggests that the expression of

89. The term noncarceral, as its root suggests, refers to criminal approaches or sanctions that are not focused on incarceration or imprisonment. 
disgust for perpetrators, far from being distinctively promising, may be a particularly inapt way of approaching this offense.

Kahan treats group-related violence as a form of expression. Vandalism, arson, threats, or physical attacks are the means by which perpetrators express their disgust for members of a particular group. Recent research on hate crimes, however, suggests that this view reflects an oversimplification: while the perpetrators of such crimes generally hold prejudiced or stereotyped views about their targets, it is inadequate and misleading to describe such attacks simply as enactments of these views. ${ }^{90}$ While some may be expressive in the way that Kahan's analysis suggests, or "instrumental" in the sense of communicating a message about group members' place in a particular community, ${ }^{91}$ many researchers analyze such acts as (self-) constitutive-part of a process through which individuals define and value themselves or the groups of which they are a part. ${ }^{92}$ These acts concern the perpetrator's identity as much as they concern the target's, although societal views of particular target groups make them promising vehicles for working out the conflicts individuals face. ${ }^{93}$ The ubiquity and force of such constitutive struggles, and the role of

90. In fact, some scholars have concluded that the term "hate crime" is a misnomer because the attacks are not motivated simply by hate or the desire to express hate. See, e.g., Howard Erlich, The Ecology' of Anti-Goy Violence, in HATE Crimes, supra note 56, at I05, 108 (rejecting the term "hate crime" because it presupposes a certain motivation on part of perpetrator); Gregory M. Herek, Psy'chological Heterosexism and Anti-Gay Violence: The Social Psychology of Bigotry and Bashing, in Hate Crimes, supra note 56, at I49, I64 (concurring in Erlich's conclusion that "hate crime" is misleading "if it implies that the attacker's motivation always is intense personal hatred for the victim's group").

91. The desire to communicate this kind of message may have had some role in the anti-Arab or anti-Muslim violence following September II. However, such violence may also have reflected struggles over group membership or masculinity. See infra notes 94-105 and accompanying text. Cultural views of Arab and Muslim Americans, and the sense of danger or vulnerability created by the events of September I1, may have made these groups a plausible target for the working out of such conflicts.

92. The term "constitutive" here is my own; I have selected it because of its relation to certain conceptual categories used by legal scholars to discuss the formation of subjectivity or identity. Psychologists and sociologists working in this area frequently use other terms including, at times, "expressive." But their explanation of such terms makes clear that perpetrators are seeking to express an emerging and frequently conflicted self-conception, or conception of a group membership. See, e.g., Herek, supra note 90, at 160-61 (describing as "expressive" functions of heterosexism and related violence, "social-expressive" violence, which is aimed at differentiating or enhancing the standing of one's social group, and "ego-defensive" violence, which is aimed at affirming elements of one's subjectivity such as heterosexuality or masculinity). This "expression" represents or is part of a process of subject formation, not simply an act of giving voice to already-established views; hence, the term "constitutive" seems to me appropriate.

93. See id. at I64 (explaining that "cultural heterosexism... defines gay people as suitable targets that can be 'used' for meeting a variety of psychological needs"). In the legal literature, the opportunistic or parasitic aspect of hate crimes has been explored thoughtfully by Lu-in Wang. See Luin Wang, Recognizing Opportunistic Bias Crimes, 80 B.U. L. Rev. I399 (2000); Lu-in Wang, The Complexities of "Hate", 60 OHIо Sr. L.J. 779 (1999). 
ambivalence and self-loathing in prompting their violent resolution, suggest that a disgust-based strategy may be a particularly ill-suited response.

One line of recent scholarship seeks to understand conflicts in "social identity" as animating hate crimes. ${ }^{94}$ This analysis is based on the understanding that the self-esteem of individuals is connected with the ways in which their group is valued relative to other groups. Sociologist Karl Hamner explains:

Being able to establish and maintain a positive group image compared with that of an out-group leads to high in-group prestige and an accompanying increase in personal self-esteem among in-group members .... This positive image is achieved [in two ways]. Manipulating symbolic capital involves elevating the in-group's status [and denigrating that of the out-group] through ... labels and descriptions. Manipulating material capital involves increasing the in-group's access to valued material resources while decreasing the out-group's access to them; violence against an out-group member is a drastic form of material discrimination. ${ }^{95}$

A group with low status may have few opportunities to manipulate either symbolic or material capital in such a way as to benefit itself. Inasmuch as physical violence can serve as a form of material discrimination, physical violence against a group subject to a particularly high level of social stigma ${ }^{96}$ may be one of the few available chances for enhancing social identity. ${ }^{97}$ Researchers note that the choice of targets in this process is far

94. See, e.g., Karl Hamner, Gay-Bashing: A Social Identity Analysis of Violence Against Lesbians and Gay Men, in HATE CRIMES, supra note 56, at 179-81; see also David Kirby, What's In a Basher's Mind?, The Advocate, Sept. 29, 1999, 26-29, available at http://www.advocate.com/ $\mathrm{html} / \mathrm{special} / \mathrm{shepard} / 795$ hatecrimes_wintro.asp (describing several group-based dynamics involved in gay bashing).

95. Hamner, supra note 94 , at $180-81$.

96. Hamner explains that "[a]s a group generally held in low regard by society, lesbians ana gay men are likely to represent a relevant out-group for all quarters of society, particularly for individuals lower in the social system." Id. at 183.

97. Some of the existing scholarship on gay bashing, particularly experientially based work that interviews or otherwise explores the identities of gay bashers, underscores this theme. It frequently identifies gay bashers as members of groups negotiating their own social stigma. See, e.g., Collins, supra note 65 (interviewing the Blue Boys, a group of self-professed gay bashers, and emphasizing their embattled working-class identities); Eric Weissman, Kids Who Attack Gays, in Hate Crimes, supra note 56, at 170-78 (describing group of teenage attackers as working- to middle-class, ethnic, and largely Catholic). Members of such groups may also be struggling to negotiate their masculinities as economically disadvantaged men, or as male members of racial or ethnic minorities, who have access to fewer of the resources or roles that help to constitute hegemonic or dominant masculinity. See, e.g., Angela P. Harris, Gender, Violence, Race, Violence and Criminal Justice, 52 STAN. L. REv. 777, 78I89 (2000); see also Kirby, supra note 94 (describing some gay bashings as crimes of economic "havenots" against perceived "haves"). However, some gay bashing and other forms of group-targeted violence take place at colleges, universities, and schools, including those in the suburbs, and may be perpetrated by privileged individuals. See, e.g., Kevin Berrill, Anti-Gay Violence and Victimization in the United States: An Overview, in HATE Crimes, supra note 56, at 33-34. These last examples are less 
from arbitrary-groups look for a target whom society, in effect, gives them "permission" to attack. ${ }^{98}$ Some scholarship suggests, for example, that both normative heterosexism and more specific social stigmatization of gays and lesbians can make them appear as natural targets to groups engaged in such processes.

Another related body of work understands hate crimes as animated by the struggles of individuals to negotiate elements of identity such as heterosexuality, masculinity, or nationality. ${ }^{99}$ One particularly rich facet of this scholarship, which spans the fields of sociology, criminology, and critical legal theory, focuses on the precarious status of masculinity in contemporary society, and the role of violence in the negotiation of masculinity. ${ }^{100}$ While the masculine gender is privileged in American society, those who (wish to) identify as "masculine" are coinpelled constantly to renegotiate the bounds of what it means to be masculine. As such, masculinity, while culturally valued, it is also a source of perpetual uncertainty and anxiety. Most men stake their claims to inasculinity with persistence and vigor, yet it can prove notoriously unstable, contradictory, and elusive. The deinands imposed by most forms of masculinity reflect inherent tensions: they demand a kind of bonding or connection with other men that it is intensely homosocial, if not homoerotic, yet demand that men refrain from any acts that might be perceived as homosexual. ${ }^{101}$ Moreover, something as ordinary as a woman's independence or another man's disrespect can undermine the most credibly staked claim to inasculinity. To coinplicate matters further, dominant forms of masculinity require forms of "intellectual mastery, technological prowess, and the rationalized control of [one's own and others'] behavior"102 that may be maccessible to many men

well explained by the social identity literature, but may be explained by theories emphasizing the negotiation of masculinity, an issue (albeit of sometimes different configuration) for men of greater and lesser privilege.

98. See Kirby, supra note 94 (citing hate-crimes expert Gregory Herek as saying "many bashers fcel a sense of permission to attack gay people"). See generally Herek, supra note 90 (describing heterosexism as creating a normative backdrop for antigay violence).

99. See, e.g., Jana Bufkin, Bias Crime as Gendered Behavior, 26 Soc. Just. 155, 157 (1999); Herek, supra note 90; Weissman, supra note 97 . For a very thoughtful introduction to the project of understanding violence as part of the effort to negotiate masculinity, see Harris, supra note 97, at 78193.

100. See, e.g., infra notes $103,105$.

101. See Eve Kosofsky Sedgivick, The Epistemology of the Closet 185-86 (1990). A compelling example of this dynamic is found in the military, where soldiers are required to live in intimate quarters and to bond intensely, yet where homosexual activity is sharply proscribed. For a thoughtful exploration of the relationship between the military and the constitution of the masculine, see Kenneth L. Karst, The Pursuit of Manhood and the Desegregation of the Armed Forces, 38 UCLA L. REv. 499 (1991); Madeline Morris, By Force of Arms: Rape, War, and Military Culture, 45 DuKE L.J. 651 (1996).

102. See Harris, supra note 97, at 784. Harris's discussion on this point takes its bearings from Karen D. Pyke, Class-Based Masculinities: The Interdependence of Gender, Class, and Interpersonal Power, 10 GENDER \& SOC'Y 527, 531 (1996). 
because of their racial or class-based status. The inability to achieve these dominant forms of masculinity encourages recourse to compensatory or rebellious forms of masculinity, which in turn engender envy or insecurity in more privileged males. ${ }^{103}$ In this identitarian minefield, two additional relations help to structure men's behavior. First, group membership can provide an important context for men to demonstrate masculinity to others. ${ }^{104}$ Men can validate their masculinity by associating with and winning the approval of those whose performances or activities mark them as manly. And second, notwithstanding differences in masculinities and contexts, violence, or physical control of others, can be a crucial activity through which to establish or maintain masculinity. ${ }^{105}$

Taken together, these relations here suggested an overarching hypothesis, that men may engage in acts of violence, particularly in the group context, in order to shore up perceptions of their masculinity. This hypothesis is borne out by many of the things that researchers have learned about hate crimes: men in groups perpetrate a significant number of such crimes; ${ }^{106}$ perpetrators frequently commit them to achieve group recognition or closeness within a group; ${ }^{107}$ young men frequently perpetrate them, ${ }^{108}$ in the throes of establishing their masculinity; and many perpetrators are men whose nonprivileged status deprives them of many resources necessary to establish dominant forms of masculinity. ${ }^{109}$ While any violence against a potentially vulnerable target might serve these constitutive

103. Compensatory or rebellious forms of masculinity may be more overt or physical, prompting envy or insecurity in more privileged (that is, middle class, educated, white, straight) men, who may fear that their more intellectual or control-based forms of masculinity will go unnoticed or will seem to fade in juxtaposition to these more palpably robust forms. For thoughtful and provocative discussions of compensatory forms of masculinity, see Pyke, supra note 102, at 531. See also RICHARD MaJORS \& Janet Mancini Billson, Cool Pose: The Dilemmas of Black Manhood in America (1992). For an illuminating general discussion of this phenomenon, see Harris, supra note 97.

104. See Harris, supra note 97, at 785-89 (describing groups associated with workplaces, pool halls, motorcycle clubs, urban gangs, and the military as sites for the demonstration and establishment of dominant and compensatory masculinities).

105. See generally James W. Messerschmidt, Masculinities and Crime: Critique and Reconceptualization of Theory (1993) (adding that men are more likely than women to commit violent crime, and probing the negotiation of masculinity as an explanation).

106. See Joseph Harry, Conceptualizing Anti-Gay Violence, in HATE Crimes, supra note 56, at 114 (suggesting that "most anti-gay violence arises out of the interaction of male groups"); Richard A. Berk et al., Thinking More Clearly About Hate-Motivated Crimes, in Hate Crimes, supra note 56, at 131 (noting that most hate crimes are perpetrated by small groups).

107. See Harry, supra note 106, at 115 ("The option of gay-bashing offers a nearly ideal solution to the status needs of the immature male."); Weissman, supra note 97, at 176 (quoting perpetrator in gay-bashing incident as saying "there was also a strong, close feeling that we were all in something together").

108. See Harry, supra note 106, at 114 (hypothesizing that age of most perpetrators of antigay violence is "in their late adolescence or early twenties"); see also Erlich, stupra note 90 (perpetrators in attacks in neighborhood and street settings tend to be younger, while those in workplace settings may be older).

109. See supra notes $94 \& 97$ and accompanying text (describing nonprivileged status of many hate-crime perpetrators). 
purposes, this theory may also explain why gays and lesbians are frequent targets of group-related violence. Aggression against groups or individuals who reflect gender nonconformity may be a way of asserting one's conformity. In addition, it may also be a vehicle for extirpating from one's own gender identity tabooed or nonconforming elements, by projecting them onto others who then become the targets of one's abuse. ${ }^{110}$

These approaches to theorizing group-related violence suggest that Kahan's proposal not only oversimplifies a complex phenomenon, but also might exacerbate it. According to either of these theories, low self-esteem, conflict, or insecurity about one's identity can fuel the kinds of urgent efforts at renegotiation that lead to violence. Thus many theorists have suggested that long-term remedies for hate crimes may involve strategies for rebuilding the self-esteem of perpetrator groups. ${ }^{111}$ Publicly characterizing perpetrators as objects of disgust would seem to pull in the opposite direction. It might induce some prospective perpetrators to resist the behavior; but it would also likely exacerbate the underlying conflicts by suggesting that they, or those who share the impulses, are low or contaminated, making resort to violence as a means of renegotiation more likely in the long run. ${ }^{112}$

110. See Herek, supra note 56, at 161-62 (characterizing violence that serves these functions as "ego-defensive" violence, and describing man who assaulted young hustler after having sex with him).

111. See Hamner, supra note 94, at 187-88 (describing remedial strategy of enhancing self-esteem of groups judged to be "at risk" for gay bashing).

112. A number of social scientists, using case studies or other clinical evidence, have identified a link between shame and a particular form of anger (described as "a kind of hostile, humiliated fury"). June Price Tangney et al., Shamed into Anger?: The Relation of Shame and Guilt to Anger and SelfReported Aggression, 62 J. Personality \& Soc. Psych. 669, 670 (1992) (summarizing research on the relationship between shame and anger). These studies report that "shame tends to initiate a particular type of anger episode, namely, an irrational and generally counterproductive rage reaction." Id; see also Helen B. Lewis, Shame and Guilt in Neurosis (1971); D.L. Nathanson, A Timetable for Shame, in The MANy Faces of Shame 1 (D.L. Nathanson ed., 1987); Suzanne R. Retzinger, Resentment and Laughter: Video Studies of the Shame-Rage Spiral, in The Role of Shame IN Symptom Formation 109 (Helen B. Lewis ed., 1987). These researchers hypothesize that in shanre, the object of judgment is not simply direct hostility toward herself. However, because shame involves the imagery of a judgmental other, the hostility that is mitially directed toward the self can be easily redirected toward that other in a kind of defensive reaction, an effort to find relief from a debilitating, self-critical response. See Tangney, supra, at 670 . A recent empirical investigation of this relation sought to refine this rough statement of a relationship by testing for anger responses among the shame prone and the guilt prone. The study found that shame proneness, which involves a tendency to feel badly about oneself while also externalizing cause or blame, is positively "correlated with anger, arousal, suspiciousness, resentment, irritability, ... and indirect... expressions of hostility," while guilt proneness, which is a tendency to accept responsibility or "negative interpersonal events" and not to extemalize blame, is negatively correlated with these characteristics. Id. at 669 . The tendency of shame to culminate in violence, however, is not directly supported by Tangney's article, which found a correlation between shame-proneness and indirect, but not direct, aggressiveness or expressions of hostility. Id. at 673-74 (discussing relation of shame-proneness and guilt-proneness to several measurcs of anger and hostility on the Self-Conscious Affect and Attribution Inventory ("SCAAI") and the Test of Self-Conscious Affect ("TOSCA")). 
In contrast, the strategies of the Arab American and gay-and-lesbian groups examined above tend to acknowledge and mitigate, rather than exacerbate, these dynamics. The "enlightenment" strategies espoused by members of both groups treat potential perpetrators as part of a larger group of presumptively receptive compatriots, an approach that conveys respect rather than derogation, while it confronts the stigma that creates available targets. The strategies of publicity and prevention used by the Lesbian Avengers and the urban Street Patrols create the visibility, solidarity, and enhanced security that make opportunistic targeting more difficult, both normatively and logistically. These approaches seem increasingly sound, and a disgust-based approach increasingly dubious, as we uncover the dynamics of group-based violence.

\section{Disgust and the Restructuring of Social Hierarchy}

A second question about the effects of disgust concerns Kahan's larger project: the use of responsive disgust to reconfigure social hierarchies. Kahan's prospects for success appear uncertain here if one considers the work of William Miller. Miller's extended, historical treatment suggests that the effects of disgust in reconstituting social hierarchy are, at best, equivocal and, at worst, reactionary rather than progressive. Why Kahan declines to draw this message from the work of his intellectual mentor seems unclear. ${ }^{113}$ Yet Miller's analysis sounds a cautionary note on the project of transforming the "conservation thesis" into a normative imperative.

To grasp the point of Miller's discussion, it may be useful to begin with his discussion of contempt. Both Miller and Kahan treat contempt and disgust as related concepts, but Miller-in a way that Kahan does not track ${ }^{114}$-offers a set of distinctions between the two. "Contempt and disgust both are key emotions in maintaining rank and hierarchy," Miller notes, "but they work in different ways." 115 Contempt tracks often subtle

While it does not document a link between shame and violence per se, this research does call into question not only the use of disgust in connection with hate crimes, but also the larger strategy of resorting to shame to enhance compliance with criminal law. It suggests that those who seem most likely to be reached by shaming strategies may respond not with an obedient reduction of the targeted behavior, but with hostile, defensive action.

113. Kahan discusses those portions of Miller's book that focus on contempt, upward and otherwise. See Kahan, The Anatomy of Disgust in Criminal Law, supra note 2, at 1629-30. In this synopsis, Kahan relates those elements of Miller's account that I discuss below; but, for reasons that he does not elaborate, he does not see them as raising questions about the normative thrust of his argument.

114. Kahan describes disgust as "becom[ing] aligned with a species of 'upward contempt."' Id. at 1629. He uses this language of alignment rather than undertaking to distinguish the concepts as Miller does. Although the language of alignment is, in and of itself, not inaccurate, Kahan's failure to distinguish the two concepts from the outset means that he lacks the analytic resources to underscore the significance of the emergence of visceral disgust in the Orwellian period that 1 will discuss below. See infra notes 125-29 and accompanying text.

I15. MILLER, supra note 2, at 220. 
social distinctions, while disgust "marks [the larger social and moral boundaries] that separate pure and impure, good and evil."116 Elaborating this distinction, Miller explains:

We usually think of disgust as much more visceral [in that disgust's frequent physiological markers: queasiness, cringing, recoiling] are generally unexpected in routine contempt and expected in routine disgust.... [C]ontempt, in contrast, usually makes do with images of space and rank-order or various styles of ridicule and derision: looking down upon or looking askance at, or simply smiling or laughing at. ${ }^{117}$

Because so many different kinds of relative rankings implicate contempt, Miller argues, it can take on a range of different styles. Of particular interest to Miller is the "upward contempt" of those ostensibly lower in the social hierarchy for those above them. Although particular species of upward contempt may be found, even in aristocratic regimes, ${ }^{118}$ upward contempt acquires particular features as conditions of social equality or political democratization emerge. Most notably, a kind of contempt involving disattending or indifference, which was once the distinctive province of the "high" in responding to the "low," becomes available as a forn of upward contempt. So far, Miller's account might seem to support Kahan's normative project, with counter-disgust (mobilized in relation to hate crimes) functioning much as does upward contempt, both reflecting and perpetuating the redrawing of social hierarchies.

But what happens as the former "lows" begin to exercise this prerogative? Here Miller's account becomes more complicated. In the two chapters on disgust, contempt, and the maintenance of social hierarchy, Miller offers two kinds of answers. The first comes from a discussion of the works of a nineteenth-century writer, William Hazlitt, who describes an ongoing struggle with servants aiming to humiliate him:

[T]hey try...to pull [their "betters"] down to their own level ... by getting up a little comic interlude, a ... homely drama out of the odds and ends of the family failings.... Any real kindness or condescension only sets them the more against you. They are not to be taken in that way. ${ }^{119}$

116. Id.

117. Id. at 218. Miller goes further to distinguish the facial expressions associated with contempt (one-sided upturned lip, head tilts) and disgust (upper lip retracted symmetrically, gape with protruding tongue), and differences in affect between the two (contempt is often ironic, disgust is earnest). Id. at 218-19.

118. Miller discusses the "feasts of misrule" in which "[k]ings and lords inoculated themselves somewhat against the risk of punctured pomposity by privileging fools and lower-class jesters who were allowed to ridicule their superiors to their faces." Id. at 222-23.

119. Id. at 227-28 (quoting William HazL.mT, ON THE KNOWLEDGe of CHARACTER 105 (1821)). 
Hazlitt casts wildly for a strategy with which to save face, but can find little, beyond an exaggerated hauteur, which focuses the inevitable humiliation by offering servants something to ridicule. Analyzing Hazlitt's dismay, Miller opines that the change may be less in the servants' ridicule than in the master's perception:

What I suspect Hazlitt observes is not his inferiors literally laughing in his face where once they never would have dared, but that now types like him care obsessively about impudence and effrontery.... The new democratic order allows for a real inversion of contempts. It is now the low who ... can treat their superiors with indifference. The waitperson cares less about you than you do about him or her. ${ }^{120}$

If this panicked self-consciousness on the part of the formerly high was the only consequence of upward contempt, Miller's work might still be understood to support it as a normative strategy. But he offers a different message in his final chapter, on "Orwell's Sense of Smell."121

This thought-provoking chapter-to which it is difficult to do justice in a brief passage-offers an extended reading of George Orwell's The Road to Wigan Pier. As a vehicle for reflecting on his own ambivalent socialism, and the prospect of nascent socialism among England's middle classes, Orwell spent time living in the industrial north midlands during the economic decline of the 1930s. In particular, he lived with a tripe merchant and his family in a small rooming house, whose squalor he recounts in excruciating detail. His host, Mr. Brooker, was "astonishingly dirty ... [a]nd like all people with permanently dirty hands he had a peculiarly intimate, lingering manner of handling things." 122 Lodgers received their bread imprinted with the black mark of his thumb, a thumb he placed "well over the rim"123 when gripping the full chamberpots he transported daily. Though socialism continues to exert an intellectual tug, Orwell finds himself overwhelmed by the filth, odor, and even manners of those in his immediate environment. This visceral sense of disgust, Miller explains, has moralizing consequences: "Mere description of the Brookers casts blame, mostly on them but also in part on the world that generates them... [T]he outward signs of filth are read as accurate mirrors of rotting and disgusting souls." 24 The result of his response to the Brookners and their immediate environment was a deeply ambivalent essay, from which Orwell's leftist publisher felt compelled to distance himself.

From this essay, Miller steps back to reflect on a larger phenomenon raised by Orwell: the "smell" of the lower classes. Though a first reading

120. Id. at 229-30.

121. Id. at 235-54.

122. George Orwell, The Road to Wigan Pier (cited in Miller, supra note 2, at 243).

123. Id.

124. Miller, supra note 2, at 244 . 
of Orwell's narrative might suggest a political commitment undone by a forceful bodily response, Miller suggests-and Orwell himself acknowledges-that the lines of influence flow in both directions: ${ }^{125}$

[O]ur senses, even our olfactory sense, are manipulable and markedly affected by our beliefs. ... Jews, blacks, or workers smelled as a matter of principle. Whether they really smelled or not, a stench would be imputed to them and presumably suggestion and wishful thinking made it so. These low engendered undeniable disgust and revulsion, so smell they must. ${ }^{126}$

This phenomenon of socially constructed odor becomes more complex and interesting when one observes its contextual variability. As Miller notes, "[t]he stench of the low seems to bear a direct relation to the anxiety they generate in the high. When out of place they smell; when safely in place they do not."127

The working-class odor born of upper-class anxiety, Miller ultimately suggests, is not triggered only by situational or role-related factors. Changes in social and political relations can also bring it to the fore. Potent belief about the smell of the working class, Miller explains at the close of the book, emerged just as social equality and political democratization had progressed to the point of making the worker a realistic threat. "[T]he advent of democratic principles," he concludes, "finally made ill manners and vulgarity not just a source of comedy but of terror and threat to those above. And that's when the working class began to reek seriously." ${ }^{28}$ This discussion renders the phenomenon of upward contempt, as explored by Miller, far more equivocal in its effects. At the very least, these juxtaposed accounts suggest that the effects of dennocratizing contempt are not knowable ex ante. But these passages may also be read as communicating a more ominous message about disgust and the democratizing impulse. Those of the higher ranks, like Hazlitt, may initially be discomfited by a show of upward contempt, but it does not take long for them to regam their footing. When they do, they answer not with the comparatively benign contempt of indifference, but with a virulent contempt that enlists visceral disgust in its cause. A perception of odor among the lower classes emerges, one might say, when all the stops have been pulled out by an embattled bourgeoisie intent on protecting its privilege. Those bearing traces of privilege, even in democratizing regimes, have more direct and convincing recourse to the visceral claims of disgust, which is, after all, a deeply

125. Reflecting on the application of this phenomenon to Wigan Pier, Miller questions whether Orwell, who had begun his stay in comparatively decent accommodations with unemployed miners, sought out the Brookers because they made "for a better story and... would also allow him to keep ... some rather cherished beliefs." Id. at 249.

126. Id. at 247 .

127. Id. at 248 .

128. Id. at 254 . 
inegalitarian sentiment. ${ }^{129}$ Its visceral nature tracks and mobilizes entrenched prejudices in a way that makes it more likely to assist the "highs" than their upwardly contemptuous compatriots. The dark suggestion on which Miller's book seems to close is that a war of disgusts is one that those less socially privileged are unlikely to win.

How this message translates in the context of hate crimes is not precisely clear. Both hate criminals, and their targets, may combine characteristics of privilege with those of disadvantage, in ways that complicate the upward or downward lines in this context. The targets of hate crimes are generally disadvantaged by race, ethnicity, or sexual orientation, but they may be economically privileged. Perpetrators of hate crimes enjoy skin privilege or conforming sexual desires, but they may be economically disadvantaged relative to their targets. An assertion of disgust by a gay or lesbian group, for example, might not be read as a pure form of upward contempt, particularly if, in some way, it implicates the economic status of a poor or working-class perpetrator. ${ }^{130}$ However, such an assertion would still be resistant expression by a socially marginal group: a group which is subject to many subtle and not-so-subtle forms of prejudice, persistently held even by many who eschew the resort to violence. If a gay or lesbian group, for example, gave voice to responsive disgust, it might find itself either subject to the kind of forceful downward contempt that Miller's discussion invokes or made to pay in some other political currency for the affront of its self-assertion. At the very least, this prospect should be sufficient to unsettle Kahan's insistent optimism that he who wields the potent weapon of disgust enhances his chances for readjusting the status hierarchy.

129. Miller explains that, while both are implicated in the maintenance of social hierarchy, disgust and contempt ultimately have different relations to a democratic social order. Miller notes:

Contempt [is] assimilable to democracy. In fact, rather than subverting democracy, it assisted it by making generally available to the low as well as to the high a strategy of indifference in the treatment of others. Contempt thus came to underwrite the basic minimal respect for persons so crucial to democracy, the style of tolerance captured by the saying "live and let live." Disgust ... is a much more powerful anti-democratic force, subverting the minimal demands of tolerance.... It does not admit of equitable distribution, and it works against ideas of equality. It paints a picture of pure and impure. ... Hierarchies maintained by disgust cannot be benign; because the low are polluting they constitute a danger; a policy of live and let live is not adequate.

Id. at 206, 251.

130. Some examples of what might be called "disgust rhetoric" aimed at hate criminals play this "class" card. The essay by Michael Collins, which I discuss in the following section is an example of this genre. See Collins, supra note 65, at 191. Alert to this danger, members of the San Francisco Gay and Lesbian Street Patrol, counseled by the Guardian Angels, adopted the convention of referring to potential attackers by the uniform, clinical, sci-fi infused term "mutant," so as to avoid making any kind of reference that might be interpreted as derogating group-based characteristics of the prospective perpetrator. See Miles, supra note 72 , at 58 . For a discussion of the potentially ambivalent implications of this choice of terms, see supra note 76. 


\section{B. Subject Effects of Disgust}

In the last section, we saw that Kahan's view of hate crimes offers a limited, expressive conception of actions that, in fact, reflect a dynamic, constitutive process. In this section, I suggest that the same may be true of his approach to enforcement. A regime of opposing hate crimes with public iterations of disgust does not simply express the views of preformed human subjects. Rather, it helps to produce those subjects, and their distinctive styles of political engagement, in ways that we must assess properly to evaluate Kahan's approach. As I will argue below, ncither the forms of subjectivity nor the forms of engagement produced by disgust give reason for optimism.

In his provocative article, Reflecting on the Subject, Bernard Harcourt has made this point with respect to another norms-based strategy for criminal-law enforcement: the "order-maintenance" style of community policing that has recently gained favor in New York City. ${ }^{131}$ Drawing on the work of Foucault, Harcourt argues that regimes of criminal justice do not simply create enforcement effects, they also create subject effectsdistinctive features of the human subjects of enforcement, and distinctive relations between state officials and those subjects. ${ }^{132}$ The "ordermaintenance" or "Broken Windows"133 regime helps to produce the "disorderly subject" that it claims to police, by "focus[ing] on the whole biography of the disorderly person, rather than the criminal act, and thereby facilitat[ing] a policy of surveillance, control, relocation, and exclusion of the disorderly." ${ }^{134}$ Though the official focus on disorderly persons and disordered neighborhoods has captured the lion's share of public attention, this regime has also produced a tendency toward increasing disorderliness on the part of the police, as indicated by rising complaints of brutality and other improper police actions. ${ }^{135} \mathrm{~A}$ full assessment of this regime's merits must thus take into account its production of disorderly actors on both sides of the "thin blue line."

Similarly, it may be useful to consider what kinds of subject effects tend to be produced by Kahan's regime of dueling disgusts. I should be

131. Bernard E. Harcourt, Reflecting on the Subject: A Critique of the Social Influence Conception of Deterrence, The Broken Windows Theory, and Order-Maintenance Policing New York Style, 97 Mich. L. REv. 291 (1998).

132. Id. at $362-85$.

133. Harcourt refers to the enforcement regime by this term because the idea for ordermaintenance policing had its genesis in an article by this title. See James Q. Wilson \& George L. Kelling, Broken Windows, 249 ATLANTIC MoNTHLY 29 (March 1982). In this article, the authors argued that signs of minor disorder, such as unrepaired broken windows in a neighborhood, communicated a signal of potential laxity in the moral and law-enforcennent order, which encouraged the disorderly to attempt further disruption, and led the orderly-who might otherwise provide a normative influence of greater rectitude and regularity-to hide or flee.

134. Harcourt, supra note 131, at 355-65.

135. Id. at 377-81. 
clear here that I am referring not to the effect of increased enforcement against hate crimes generally (say through increased penalties, or refusals to consider attitudes of prejudice in mitigation), but to the effects of increased enforcement against hate crimes through the public articulation of disgust. A preliminary question is whether this strategy helps to produce those subjects it claims to enforce against. My arguments above suggest some basis for reaching an affirmative conclusion.

The language of disgust may help to generate the disgusting subject by homogenizing, in the public mind, a group of defenders that are in fact differentiated. Some social scientists have stressed the importance of identifying subtypes of bias offenders. ${ }^{136}$ There may be normative and strategic reasons for distinguishing between perpetrators who engage in lethal assaults and teenagers who spew epithets or hurl fruit at their targets ${ }^{137}$ that are ill-served by unifying expressions of disgust. Moreover, as noted above, the expression of disgust may also help to generate the morally monstrous behavior it claims to protest. If meaningful human contact with members of a targeted group is a catalyst for the reconsideration of prejudices, ${ }^{138}$ then the effective exile of the offender, from his victims and the larger, "decent" society, promoted by this style of discourse may permit devaluative attitudes to go unchallenged. Moreover, if Iow self-esteem or ambivalence about elements of one's identity may create the preconditions for sometimes-violent renegotiations of one's self-conception, then the intense stigmatization that may follow from public iterations of disgust may increase rather than decrease the incidence of bias-related violence. ${ }^{139}$

More interesting, however, are two questions that most regimes of criminal enforcement tend to obscure from view. First, what kind of "enforcing subjects" does the regime help to produce? Second, what styles of interaction between those subjects and the subjects of criminal enforcement does the regime tend to promote? One of the perplexing flaws in

136. Antigay violence, for example, may be perpetrated by those adults who commit deadly assaults and random beatings upon adult lesbians and gay men; those teens who commit assaults or perpetrate harassment against their gay and lesbian peers; and (most prevalent) youths who commit "sissy bashing" against gender-nonconforming boys. See Harry, supra note 106, at 116-17; see also Irene R. Bush \& Anthony Sainz, Competencies at the Intersection of Difference, Tolerance, and Prevention of Hate Crimes, 13 J. GAY \& LesBian Soc. SeRvices 205, 214 (2001) (discussing Harry's work in context of profiling "gay bashers").

137. See Weissman, supra note 97 , at 170 (interviewing teenagers a year after an incident where they threw oranges and eggs at gay men and finding several who condemned their earlier actions as wrong and expressed personal or political support for gays and lesbians).

138. See Bush \& Sainz, supra note 136, at 209 ("Attitude change toward oppressed groups is most likely to be achieved when information about the subject is broad (dispelling myths) and when there is a positive exposure to members of the population."); Eric Tischler, Can Tolerance be Taught? Understanding and Reducing the Incidence of Hate Crimes, 61 CoRrections TODAY 76 (1999) (finding that intergroup contact in personal context ameliorates gang attitudes about certain racial groups that can lead to violence).

139. See supra text accompanying notes 111-12. 
Kahan's theory of social influence is his assumption that "they," the objects of enforcement, may be shaped, at least in some aspects of their behavior, by the enforcement regime, while "we," the enforcement officials and other law-abiding citizens in whose name they act, remain untouched and unmarked by the regime's operation. If this kind of error constituted an important oversight in the "Broken Windows" regime-a regime secured prinarily by changes in policing patterns, it is far more crucial an oversight in a regime that demands a particular characterization of the criminal offender, not only from enforcement officials, but from targeted groups and other members of the public. ${ }^{140}$ Who is the "disgusted subject," and what forms of political engagement might this subject carry in her wake?

As commentators such as Toni Massaro and Martha Nussbaum have noted, the disgusted subject can be a deeply threatening character. ${ }^{141}$ This subject, as Massaro has observed, is prepared to draw sharp distinctionsotherwise blunted by the bonds of humanity-between herself and the object of her disgust. This may permit her to treat whole categories of people as "less than human others who deserve our contempt." 142 Additionally, it may make her less sensitive to arguments about distinctions among members of an offending group and less reachable by arguments about gradations in punishment for those convicted. ${ }^{143}$ This is a potentially damaging error in the realm of hate crimes, where some offenses are both starker and more ominous in their implications about the offender than others. ${ }^{144}$ Both

140. 1 argue below that criminal-law regimes that attempt to produce (or perpetuate or accelerate) normative change rely strongly on efforts by citizens and community groups, as well as on those by law-enforcement officials. See infra Part IV. While I suspect that Kahan is more confident than 1 am that changes in policies and pronouncements by enforcement officials will go a long way toward producing the desired changes among citizens and community groups, it is still the case that the change required by his proposal regarding hate crimes appears to require changes among a wider and more varied group of actors than the order-maintenance policing regime critiqued by Harcourt.

141. For a truly illuminating exchange about the public deployment of disgust, which helped in many ways to form my views on the subject, see THE PAssions of LAw, supra note 2, at Part I. This exchange includes Kahan's article, Kahan, The Progressive Appropriation, supra note 2, Nussbaum's article, Nussbaum, supra note 24, and Toni Massaro's comprehensive and incisive analysis of shameand disgust-based regimes, Toni M. Massaro, Show (Some) Emotions, in The Passions of Law, supra note 2. See also Toni M. Massaro, The Meanings of Shame: Implications for Legal Reform, 3 Psychol., PUB. PoL'Y \& L. 645 (1997) [hereinafter Massaro, The Meanings of Shame].

142. See Massaro, supra note 141, at 699.

143. See Massaro, Show (Some) Emotions, supra note 141, at 99. If our disgust at the act simultaneously provides the justification for criminal enforcement and severs our potential bonds to the accused, there would seem to be little ground from which one could argue for mitigation or lenity in sanctions.

144. See, e.g., Weissman, supra note 97 . The youths interviewed by Weissman, who threw eggs and oranges at a group of people they identified as gay men, contrast sharply with someone like Stephen Roy Carr, for example, who shot Claudia Brenner and her lover at close range, then alleged that their lesbian lovemaking had precipitated his attack. Weissman's interviewees also vary interestingly among themselves, in the refiection and regret they manifest over their actions, and in their willingness to see gays and lesbians as equal human beings deserving of diguity and public opportunities. 
Massaro and Nussbaum call our attention to the possible devastation that might be wreaked in retribution, once these offenses are unmoored from the constraints imposed by a perception of common humanity. Nussbaum's invocation of the Third Reich-the political production of the ultimate disgusted subject-and the trial of Oscar Wilde are chilling reminders of the excesses such subjects can perpetrate. ${ }^{145}$

Yet we need not witness a Hitler, or even a Justice Wills, to feel the effects of disgust on forms and styles of public engagement. A regime promoting public expressions of disgust seems likely to affect political engagement in more quotidian ways that also deserve our concern. A regime that "fights disgust fire with disgust fire," for example, risks making our political discourse more visceral. William Miller has observed that disgust "puts our body behind" our political judgments; ${ }^{146}$ one may legitimately wonder whether this is a good thing.

Martha Nussbaum has observed how strikingly inarticulate disgust can be, when it is compelled to justify itself in the public domain. Though it may reflect a form of evaluation, as Kahan suggests, disgust also mvokes a visceral, often physiological response that is capable neither of explaining itself nor of inducing a similar response in others if not instinctively shared. Nussbaum notes, for example, that in the debate over Colorado's Amendment $2,{ }^{147}$ a measure she properly describes as being grounded in disgust at gays and lesbians, proponents were unable to make their case without drawing inappropriately on the idioms of danger (gays will threaten your children) or indignation (legislation favoring gays deprives the real victims of civil-rights offenses). If proponents restricted their recourse to the domain of disgust, they would have to assert that gay men "eat feces and drink raw blood," 148 or some similarly visceral attempt to induce revulsion in the unpersuaded. Nussbaum does not treat this as a realistic possibility; indeed, in the Amendment 2 debate, a confused or indiscriminate public permitted disgusted proponents to rely on justifications unrelated to the emotional ground of their proposal.

But what is likely to happen if expressions of disgust are valorized over expressions of indignation and other similarly reason-giving forms of public discourse? We might look, in answering this question, to an area Kahan praises for its potential to illuminate and produce choice among competing disgust sensibilities: the debate over the public funding and

145. See Nussbaum, supra note 24 , at 29-30, 46-47.

146. MilleR, supra note 2, at 181.

147. Colo. Const. art. II, $\S 30 \mathrm{~b}$ (repealing municipal ordinances that prohibit discrimination on the basis of "homosexual, lesbian or bisexual orientation, conduct, practices or relationships" and prohibiting similar legislation at the state or local level without further constitutional amendment). Amendment 2 was struck down under the 14th Amendment's Equal Protection clause in Romer v. Evans, 517 U.S. 620 (1996).

148. Nussbaum, supra note 24, at 27-28. 
display of controversial visual arts. ${ }^{149}$ As recently exemplified in the controversy over Chris Ofili's The Holy Virgin Mary, a work that combines an African depiction of Mary with cutouts of female genitalia and pieces of elephant dung, the contending disgusts were vividly in evidence, but the clarification predicted by Kahan did not emerge. Former Mayor Rudolf Guiliani withheld municipal funding from the Brooklyn Museum of Art, where the painting was exhibited, calling the work "sick stuff,"150 and "human excrement," which should not be displayed because "civilization has been about finding the right place to put excrement."151 Cultural critic Camille Paglia also weighed in, charging "a Jewish collector" and "a Jewish museum director" with "Catholic-bashing."152 Defenders of the painting, and of public funding of the arts returned the fire, with the usually-cogent Katha Pollitt dismissing censorious critics as "an amalgam of high culture reactionaries, antigovernment ideologues and faux populists." 153 These escalating salvos of revulsion ultimately produced more heat ${ }^{154}$ than light. ${ }^{155}$ When Judge Nina Gershon enjoined Mayor Guiliani from any content-based retaliation against the Brooklyn Museun, some commentators declared a temporary victory for freedom of expres$\operatorname{sion}^{156}$, but few believed that the moral and aesthetic issues raised by the work had been clarified, let alone resolved. ${ }^{157}$

149. Kahan, The Progressive Appropriation, supra note 2, at 65.

150. Sensational Art, Christian Century, Oct. 20, 1999, at 989.

151. Katha Pollitt, Catholic Bashing?, in SubJect to Debate: SENSE and Dissents on WOMEN, POLITICS, AND CULTURE 287-90, 290 (2001) (describing controversies over funding of the NEA and specific examples of provocative contemporary art); see, e.g., KATHA PolLITT, Honk If You Like Art, in Subject to Debate: Sense and Dissents on Women, Politics, and Culture 287-90 (2001) (same).

152. Harvey Blume, Oops, She Did It Again, AM. Prospect, Apr. 23, 2001, at 4041.

153. See PollitT, Honk If You Like Art, supra note 151, at 190-92 (characterizing the "anti-NEA phalanx").

154. I will not pretend to be neutral in this cacophonous debate. I find Katha Pollitt's critique of National Endowment for the Arts opponents and related critics far more persuasive than Rudy Guiliani's condemnation of The Holy Virgin Mary exhibit. This is true, however, not because Pollitt lobs disgusted barbs, but because she frequently combines them with more substantive strategies. Her persuasive bite comes from those sections of her essays in which she actually describes the art in question and the affective or intellectual response that it produces, not those sections in which she expresses contempt (for her response is probably closer to contempt than disgust) for their opponents.

155. Interestingly, in this debate, one of the more reflective considerations of the aesthetic and political norms at issue, and what, in particular, may have animated the manifestations of disgust at the painting, was provided by a Catholic periodical. See e.g., George Wilson, Furor over Painting Reveals Conflicted Attitudes Toward the Body, Sexuality, 36 NaT'I CATHOLIC REP. 21 (1999).

156. See e.g., Lee Rosenbaum, The Battle of Brooklyn Ends, the Controversy Continues, ART IN AM., June 1,2000, at 39. Guiliani's obligation to contimue funding the museum could, of course, have been established without recourse to manifestations of disgust on either side. It is interesting to note, however, that Guiliani greeted the decision with a return to his preferred expressive form, dismissing it as "the usual knee-jerk reaction of some judges." See Mary Schmidt Campbell, Collisions at a Museum, THE NATION, Nov. 22, 1999, at 5 .

157. See e.g., Rosenbaum, supra; Campbell, supra. It is likely that such debates will not, and probably should not, be definitively resolved, given the aesthetic and normative pluralism that 
But we may ultimately count ourselves lucky if we are able to achieve even this cacophonous response. Another, more worrisome characteristic of disgust is its tendency to induce a kind of political lassitude in many who experience it. Miller notes this point in a brief, yet revealing, tour of the moral failings of the sentiment. Remarking on the way in which our disgust for a wrongdoer may bleed onto the state he induces in his victim, Miller observes:

[Disgust] also has a style of negativeness, a depressed and depressing style that makes us uncomfortable. Compare fiery indignation with dour, phlegmatic disgust.... Disgust recoils at what we are and what we do, both the voluntary and the involuntary. Indignation, for all its vengeful fury... [puts] the world back in order, and ... gives us reasons for living. Disgust gives us reasons for withdrawing. ${ }^{158}$

Michael Collins' provocative and revealing essay, The GayBashers, ${ }^{159}$ powerfully illustrates this point in the hate-crimes debate. Collins interviewed a group of self-professed gay bashers who call themselves "the Blue Boys" to get a glimpse of what animates them and, more importantly, to determine whether they might be the perpetrators responsible for the bat-inflicted beatings of gay men in several neighborhoods of Los Angeles. The interview was undoubtedly challenging to conduct. The Blue Boys are alternately slovenly and reflexively militaristic and make no effort to conceal their casual adulation for Adolf Hitler or their searing contempt for their targets. However, in the face of this self-presentation, Collins makes an interesting journalistic choice. Abandoning the posture of objectivity characteristic of the mainstream journalism for a hip, vernacular kind of aesthetic, Collins makes no effort to conceal his frank disgust for the Blue Boys. He tells us about the smell of the apartment ("your basic beerhead single man's dive"), ${ }^{160}$ in which the interview takes place, and about the size of the ringleader's "beer-belly;"'161 he identifies spelling errors in the group's statement of principles, finds the leader's cartoon sketches to reveal "a profoundly disturbed man,"162 and describes him as "sound[ing] like a babbling speed freak" 163 as he tries to justify the group's activities. This essay treats the reader to the bizarre and somewhat dizzying spectacle of the Blue Boys' vitriolic inanities competing for airtime, and

characterizes this country. However, if such a pluralism of perspective is regarded as a positive good, the manifestation of disgust in public debate may make a negative contribution, because it polarizes the contending positions and prevents their full expression or consideration.

158. MILLER, supra note 2, at 204.

159. Collins, supra note 65 , at 197.

160. Id. at 193.

161. Id.

162. Id. at 195.

163. Id at 197. 
even for noral credibility, with Collins' casually but persistently contemptuous judgments.

But as one approaches the point of overload, one glimpses something striking about Collins' narrative: he seems to become enervated as well. He turns, virtually without comment, from the Blue Boys to the police investigation of the neighborhood violence, evincing a more muted brand of contempt for the LAPD's failure to identify and respond to hate crimes. ${ }^{164}$ He concludes by surveying the facts of a series of bashings, with scarcely an effort to reach a conclusion about whether the Blue Boys might be responsible. Collins closes his essay with the words of a victim, describing his reclusiveness in the wake of an attack: "I don't walk any more. You just can't do it with this going on. It's just such a sick thing."165 This quote reflects the reasonable response of the victim of a particularly brutal attack; but it also epitomizes the dangers of Collins' disgust-soaked approach. When it's all so sick-and the unredeemed sickness of those around you is your primary focus-you really can't go out anymore. Disgust, while often inflammatory, can also be exhausting. This exhaustion may not dissipate, as the sentiment, in and of itself, offers no possibility for forward movement. Apparently spent by his variously articulated revulsions, Collins can barely tie up the strands of his story. There is nothing here of the resolute will of the Muslim activist heading off to yet another panel discussion, or of the provocative energy of the Lesbian Avenger contemplating alternate forms of direct action. A conviction that something better is possible, or that wrongs can be exposed and avenged, provides a political fuel that disgust cannot offer. The most ominous and perhaps the most likely political effect of a regime of disgust may be not cacophony or conflagration, but deinoralization and political lassitude.

\section{CoNCLUSION}

If a disgust-based approach to hate crimes is deeply flawed, yet hate crimes reinain an urgent problem, we must consider what kind of approach should be offered in its place. Two elements of Kahan's approach may help us in fashioning a more appropriate response. The flrst, and more specific, is his endorsement of enhanced penalties for hate crimes or group-based violence. The judgment behind such penalties can be grounded on indignation at the unjust and unequal treatment they perpetrate, as easily as on disgust; they can be an important way of "[e]xpressing outrage, making clear what is unacceptable, and refusing relationships with those who commit

164. Id. (noting that "many official of the LAPD ... distinctly seem to have a policy of playing down 'gaybashings,' which is apparently to avoid criticism that the force is not doing enough by way of preventive patrolling").

165. Id. at 200 . 
evil."166 The second, broader element that I would draw from Kahan's analysis is his insight that the social norms underlying injurious social practices may be the key to their successful regulation. This emphasis on norms, to my mind, makes enforcement efforts more complex, for it requires more than the enactment of particular statutes or the pronouncements of particular enforcement officials to produce (or perpetuate) normative change. It requires efforts by a range of individuals and organizations within the affected communities. ${ }^{167}$ I can only gesture toward the crucial norms and how they might be taken up by enforcement officials and community groups. Still, a few observations may be helpful in envisioning an alternative path.

The norms that facilitate hate crimes, contemporary research suggests, may have less to do with attitudes toward the perpetrators than with attitudes toward their targets. Hate-crime offenders-in the several psychological processes that drive them-tend to be opportunistic in their choice of targets: they attack those whom society has identified as expendable or as deeply devalued. As psychologist Gregory Herek says of antigay attacks: "The main thing coming from research is that many bashers feel a sense of permission to attack gay people. They perceive that gays aren't valued in our society, which makes them easy targets."168 The norms that merit legal and public attention, therefore, are the ones that commumicate this message. This focus suggests that indignation, which seeks to explain the inappropriateness of particular treatment of a given subjects, ${ }^{169}$ will be more important to enforcement efforts than to disgust, which in its focus on perpetrators may be wholly unenlightening about the inappropriateness of particular action toward a target group.

This normative focus also suggests a direction for the activities of community groups and the practices of law-enforcement officials. This direction is demonstrated not by Kahan's proposal, but by efforts of

166. Martha Minow, Between Vengeance and Forgiveness: Facing History AfTer GENOCIDE AND MASS VIOLENCE 18 (1998). Minow here refers to a response to genocide, but her words seem to me equally applicable to hate crimes. For a detailed discussion of the implications of considering group-based violence as "opportunistic" for the revision of federal criminal laws, see Wang, Reorganizing Opportunistic Bias Crimes, supra note 93, at 1418-35.

167. Whether Kahan would agree with me here is difficult to determine. On the one hand, his disgust- and shame-related proposals focus heavily on actions or pronouncements of public officials to generate normative change. Thus it may appear that, because his emphasis is, to some degree, on incentivising normative change by causing the norms of the conforming community to bear more heavily on nonconformers, his enforcement efforts are more "top-down" and less diffuse than what I will gesture toward here. However, it must also be considered that Kahan does not purport entirely to change norms, but rather to render public, and therefore hasten, a change in norms that are already in the process of transformation. My position below will be that norms are more in need of change than they are already changing. One might conclude that an effort to produce change requires a more systematic and diffuse remedial strategy.

168. Kirby, supra note 94 , at 29 ; see also Herek, supra note 90.

169. See Nussbaum, supra note 24 . 
recently targeted groups, such as Muslim and Arab Americans or gays and lesbians. If, as researchers and target-group activists have argued, regular contact, greater knowledge, and opportunities for collaboration help to lessen devaluation, community groups and enforcement officials who want to insist on the value and protected status of all groups should develop programs to enhance such contact. This approach has recently been applied in the corrections context, where officials have used collaborative, intergroup projects to address the antipathies underlying racially driven gang violence. ${ }^{170} \mathrm{~A}$ similar approach might similarly become a focus of community groups, assisted by community-policing staff.

A second imperative is to tie these more general efforts at combating devaluative norms to the specific context of hate crimes. This involves increasing public awareness of the link between devaluation and verbal and physical attacks, and communicating to potentially targeted groups the ways in which communities stand ready to protect them. This was the strategy behind Lesbian Avengers' efforts to identify particular incidents as hate crimes, and behind gay patrol groups' efforts to create safer streets. Yet such strategies must not be limited to self-help efforts by the affected groups. The Anti-Defamation League, for example, has advocated setting special hate-crimes units within local law enforcement that will work on the community-policing principles of regular, systematic interaction with neighborhoods and community groups. ${ }^{171}$ The Anti-Defamation League also advocates that law-enforcement officials set up standardized hatecrime reporting systems and develop articulated criteria for determining whether crimes were bias motivated. ${ }^{172}$

Communities can buttress support such enforcement efforts through initiatives aimed at showing support for and solidarity with targeted group members. This happened in some of the most poiguant moments following September 11, when neighbors and community groups not only rallied in support of Arab and Muslim Americans, but resolved, in some very limited way, to share their plight. It occurred when community groups provided escorts to accompany identifiably Muslim women on their daily errands, ${ }^{173}$ when individuals offered to take Arab American neighbors imto their hoines, ${ }^{174}$ and when Christian neighbors and interfaith groups gathered outside mosques and Islamic centers at night. ${ }^{175}$ These efforts to "form a

170. Tischler, supra note 138 (describing expert and prisoner-advocate programs that bring inmates of different races together in collaborative efforts such as games, simulations, and projects).

171. Michael Lieberman, Hate Crimes: Policies and Procedures for Law Enforcement Agencies, ANti-Defamation League Rep. 3 (1988), available at http://www.lexis-nexis.com/ciuniv (last visited Apr. 27, 2002).

172. Id. at $3-4$.

173. See Kaufman, supra note 39.

174. See Murphy, supra note 47.

175. See id. 
partnership with the oppressed and tyrannized"176 serve to enhance the security of potentially targeted group members, by displaying community resolve and making attacks more difficult. They can also subvert unreflective stigma, by blurring the boundaries between "insider" and "outsider" that make targeting possible.

Violence aimed at groups remains a daunting problem, rendered volatile both by geopolitics and by our nation's own festering hierarchical wounds. Yet recent mobilizations suggest that targeted groups in many communities are working with creativity and resolve to try to ameliorate the dangers. Deploying their strategies to produce normative change in the attitudes toward targeted groups holds out greater promise than a regime of publicly articulated disgust, which underestimates the complexity of the phenomenon it claims to address, and threatens both to impoverish and to enervate our political domain. 